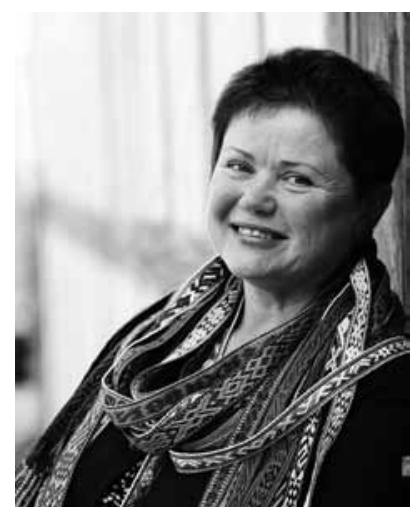

Elena Matulionienè - KU etnologijos mokslo krypties doktorantè.

Moksliniai interesai: tautodailè, tautinis kostiumas. Adresas: Herkaus Manto g. 84, LT-92294 Klaipeda. El.paštas: elenamatul@gmail.com.

Elena Matulionienè: PhD student of Klaipèda University. Research interests: folk art, folk costume.

Address: Herkaus Manto g. 84, LT-92294 Klaipeda.

E-mail: elenamatul@gmail.com.

\title{
Elena Matulionienè
}

\author{
Klaipédos universitetas
}

\section{BALTIJOS REGIONO TAUTINIO KOSTIUMO KIŠENIŲ ORNAMENTIKA}

\begin{abstract}
Anotacija
Straipsnio tikslas - nustatyti lietuvininkių delmonu bei kaimyninių tautų kišenių dekoro tipologines charakteristikas: ornamentų elementų komponavimo būdus, ornamentų motyvus, jų tarpusavio koreliaciją ir paplitimą. Šiame straipsnyje aptariami Klaipedos krašto lietuvininkių ornamentais dekoruoti delmonai, esčių, suomių, švedžiu ir norvegių tautinio kostiumo kišenės bei muziejuose išsaugoti ịvairių tautų aukštuomenès aksesuarai (parišamos kišenès, reticules). Kišenių dekoras tiriamas norint pagrịsti arba paneigti aukštuomenès madų ir tarptautinių ryšių įtaką liaudies kostiumo dekoro formavimuisi ir kaitai. Tyrimas leido nustatyti kišenių dekoravimo būdus, siužetinio ornamento derinimo ypatumus.

PAGRINDINIAI ŽODŽIAI: delmonas, lietuvininkès, kišenè, dekoras, ornamentas, kompozicija, skiautinys, aplikacija, siuvinèjimas.
\end{abstract}

\begin{abstract}
The purpose of the article is to determine the typological characteristics of decoration of the delmonas of Lithuania Minor and of the national costume pockets of neighbouring nations. This article discusses Klaipeda region delmonas, the pockets of Estonian, Finnish, Swedish and Norwegian costume, and the attachable pockets of noble class's attire of various nations preserved in museums. The decorations of the pockets were studied to support or refute the influence of the fashion of nobility and of international relations on folk costume decor formation and change. The research allowed to identify the decorating techniques, pattern variation and matching features of the pockets.
\end{abstract}

KEY WORDS: delmonas, pocket, Lietuvininks, decoration, ornament, composition, patchwork, embroidery. 
Itvadas

Klaipèdos krašto gyventojos lietuvininkès kaip tradicinès aprangos priedą dèvejo prie juosmens po prijuoste parištą spalvingą išorinę kišenę (rankinę) smulkiems daiktams nešiotis. Ši praktiška, o kartu ir puošni aprangos detale kostiumo istorijoje žinoma jau nuo XVI a. İvairių formų rankinès iš brangių medžiagų, gausiai dekoruotos, nešiotos pakabintos ar parištos ties juosmeniu po viršutiniais drabužiais (sijonu, prijuoste), o nuo XVIII a. - rankoje ant dirželio ar grandinèlès. Tai buvo ne tik praktiškas aksesuaras, bet ir moters socialinị statusą parodantis aprangos elementas. XVII, XVIII a. ir XIX a. pradžioje moterų kostiumą sudare daug (vienas ant kito dévimų) elementų, todèl viena ar dvi parištos kišenès galèjo būti nepastebimai nešiojamos po sijonų klostėmis. Dažniausiai kišenès buvo rišamos poromis ir kabėjo po vieną ant abiejų klubų. Tokios kišenès Europoje tarp aukštuomenès buvo populiarios iki pat XIX a. vidurio. XIX a. pradžioje ši mada pasiekè ir žemesnius gyventojų socialinius sluoksnius. Rankinukai (kišenès) buvo gaminami iš įvairiausios tekstilès, dažnai siuvami pačių moterų, dèvimi ir ant viršutinių drabužių (sijonų, prijuosčių, sarafanų). Per daugelị metų liaudies aprangoje ši detale iqgijo savitų bruožų: susiformavo ir i̇sitvirtino skirtingos kišenių formos, dèvèjimo būdai, apdaila ir dekoras. Šiandien parišama ar prikabinama puošni kišenè yra pageidautina daugelio Europos šaliu etnografinių regionų tautinio kostiumo detalè. Kišenių gausa ir įvairove pasižymi norvegų, švedų, estų, suomių moteriški tautiniai kostiumai. Ju turi ir atskiri Rusijos, Ukrainos, Vokietijos regionai. Lietuvoje ši kostiumo detalè, vadinama delmonu, buvo paplitusi Klaipèdos krašte (Prūsų Lietuvoje ${ }^{1}$ ).

\section{Publikacijų bei šaltinių apžvalga}

Klaipėdos krašto lietuvininkių delmonų ornamentikos tyrimai kreipiant dèmesį į formas ir dekorą autorés publikuoti 1995 bei $2005 \mathrm{~m}$. (Matulioniené 1995, 2005a, 2005b). Lietuvininkių bei kaimyninių tautų rankdarbių apžvalginiai lyginamieji tyrimai skelbti 2006 m. Klaipèdos krašto (30 vnt.) delmonai lyginti su švediškomis (13 vnt.), suomiškomis (14 vnt.) ir norvegiškomis (11 vnt.) kišenėmis (Matulionienè 2006). Šiame straipsnyje analizuojami autorès per pastaruosius ketvertą metų muziejų ir asmeniniuose fonduose, kataloguose, publikacijose bei kituose informaciniuose šaltiniuose ir lauko tyrimų metu surinkti duomenys. Išlikę delmonai yra pagaminti nuo XIX a. vidurio iki XX a. 4-ojo dešimtmečio.

Estijos kišenès ir maišeliai iš Estijos liaudies muziejaus rinkinių išsamiai nagrinèti Eevi Astel ir publikuoti muziejaus išleistame kataloge (Astel 2006). Šio

Vok. Preussisch Litauen (rečiau - Litauischer Kreis, Litauische Ämter, Provinz Litthauen) - istorinis-etnografinis Prūsijos, o vèliau Rytprūsių regionas, apėmęs šiaurrytines Prūsijos provincijos dalis, kuriose gyveno lietuvininkai. 
katalogo įvadiniame straipsnyje aptarti muziejaus kolekcijos kišenių gaminimo būdai, dekoravimas. Pateiktos 32 tekstilinių maišelių nuotraukos ir metrikos. Kiti estiškų kišenių pavyzdžiai surinkti iš autorès (E. M.) asmeninio fotoarchyvo (20 vnt.), tautinio kostiumo pristatymo publikacijų (Arbet 2004) ir muzieju internetinèse prieigose (78 vnt.). Ivairiu tipu maišeliai aptinkami kone visoje Estijos teritorijoje, tačiau daugiausia pavyzdžių ir puošniausi eksponatai sukaupti iš Saaremos salos gyvenviečių. Šiuo metu turimais duomenimis, muziejuose saugomos siuvinètos estiškos kišenès gamintos nuo XIX a. pabaigos iki XX a. 5-ojo dešimtmečio. Ankstyviausia kišenè iš Pietų Saaremos² pagaminta $1890 \mathrm{~m}$.

Suomijos tautinių kostiumų tyrinètojų publikacijose (Sirelius 1906, Sirelius 1922, Kansallispukuja 1991, Keskipoikela 1997, Holst 2011), Suomijos rankdarbiu muziejaus, Suomijos tautiniu drabužiu centro bei Suomijos tautiniu drabužiu tarybos kuruojamame internetiniame puslapyje $\mathrm{e}^{3}$ pristatomuose regioninių kostiumų komplektuose pateikiami moteriškų kišenių pavyzdžiai, dẻvèti trylikoje iš devyniolikos Suomijos etnografinių regionų. Suomijos liaudies muziejaus kolekcijos kišenes (108 vnt.) analizavo nacionalinių kostiumų tyrèja Holst Leena ir nacionalinių kostiumų konsultantė Somerma Ritva. Publikacijoje „Tradicinis tautinių kostiumų kūrimas“ (Somerma 1983) pristatyti suomiškų kišenių gamybos būdai, audiniai bei formos. Duomenys apie dekoravimą autorès (E. M.) surinkti remiantis eksponatų nuotraukomis. Marketta Luutonen ${ }^{4}$ tyrimų duomenimis, parišamos kišenès vakarinejje Suomijos dalyje paplito XVIII a., o rytinèje - XIX a. pradžioje.

Švedijos regionų tautinių kostiumų kišenių apžvalgai medžiaga rinkta publikacijose (Berg 1978, Bergman 2001, Duran 2011, Duran 2012), muziejų internetiniuose puslapiuose ${ }^{5}$ ir tautinio kostiumo pristatymuose tarptautiniuose folkloro festivaliuose: Lietuvoje, Estijoje, Švedijoje (autorès E. M. fotoarchyvas). Šiam tyrimui surinkta kišenių pavyzdžių iš penkiolikos Švedijos regionų. Didžiausia kišeniu įvairove pasižymi šalies centrinejje dalyje esantis Dalarnos regionas, kurio teritorijoje dèvètos skirtingų formų ir puošybos kišenès. Švedijos nacionalinis kostiumas sukurtas tradicinio kostiumo (tradicinès aprangos) nuo 1830 iki $1900 \mathrm{~m}$. pagrindu. Buvo remiamasi muziejuose išlikusiais autentiškais pavyzdžiais, nuotraukomis bei dailininkų piešiniais ${ }^{6} .1800$ ir 1863 m. spalvotų

2 ERM A 509: 5163.

3 http://www.kansallispuvut.fi/info.htm

4 Marketta Luutonen. Laukku, ihmisen paras kaveri. http://www.ennenjanyt.net/2006_2/referee/ luutonen.pdf

5 http://foreverswedish.net/folk-draumlkt.html; http://www.sverigedrakten.se/ - Šiaurès šaliu muziejus, Stokholmas, Švedija.

6 Menininko Odnes 1774 m. nupieštas piešinys eksponuojamas Heseberg Gård muziejuje, kuris yra Norderhov (Nordehove). $1800 \mathrm{~m}$. įvairių Švedijos regionų tautinių kostiumų komplektų akvarelès 
akvarelių ir techninių piešinių kolekcijos pateikia duomenų apie kišenių formas bei dekorą. Pavyko surasti regioninių kostiumų piešinių su kišenėmis iš Dalarnos (Leksand, Mora, Gagnef, Rättvik, Siljan, Ore, Falun) bei kitų Švedijos regionų: Västergotland, Gotland, Hälsingland, Värmland, Uppland. Muziejuose išsaugota XVIII a. bei XIX a. pradžios autentiškų kišenių iš Dalarnos (Leksand, Gagnef).

Norvegijos moteriško kostiumo kišenių pavyzdžiai siekia 1750-1830 m. Kišenès yra iš Vakaru Agder muziejaus iš Mandalo. Daugiausia norvegiškų kišenių surasta muziejų internetinèse svetainėse (40 vnt.) ir tautinio kostiumo publikacijose (20 vnt.) Autentišku pavyzdžiu pateikta Lailos Duran ir Heidi Fossnes leidinių fotografijose (Duran 2011, Duran 2012, Fossnes 1995) ir autorès nuotraukose (E. M. fotoarchyvas).

Kaip jau buvo minėta, istorinio kostiumo tyrèjų Sigrid Ivo (Ivo 2011), Leenos Holst (Holst 2011), Johannes Pietsch ${ }^{7}$, Barbaros Burman ${ }^{8}$ publikacijose laikomasi nuomonès, kad liaudies kostiumo kišenèms turèjo ịtakos aukštuomenès maduc tendencijos. Siuvinèti aksesuarai (parišamos kišenès, tabako maišeliai, batai, šlepetès, miegojimo kepurès) aukštuomenejje buvo populiarūs keletą XIX a. dešimtmečiuc. Spalvingi raštai buvo siuvinejjami pagal raštų lapus, importuotus iš Berlyno. Autorès surinkti duomenys leidžia daryti prielaidą, kad nemaža dalis ornamentų motyvų, aptinkamų liaudiškų kišenių dekore, buvo populiarūs aukštuomenės moterų siuvinètuose rankdarbiuose. Adaptuoti pagal liaudies grožio suvokimo ir ornamentikos pritaikymo dèsnius tautinio kostiumo detalèse, jau kaip tradicinio dekoro pavyzdžiai, jie išliko iki mūsų dienų. Šiai prielaidai paremti aukštuomenès aksesuarų (kišenių, rankinių) pavyzdžių ieškota muziejų internetinėse prieigose bei publikacijose. Autore dèkinga Southampptono universiteto projekto apie rankines kūrëjams ${ }^{9}$, sudariusiems sąlygas šių eksponatų paieškai žymiausiuose pasaulio muziejuose. Keliamas klausimas, ar surasti ir nagrinejjami įvairių tautų aukštuomenès aksesuarai (70 vnt.) gali būti teisètai laikytini liaudiškų kišeniu prototipais.

Šiandien yra išlikę 82 lietuvininkių delmonai (autentiški pavyzdžiai, nuotraukos, piešiniai), iš kurių 67 yra dekoruoti ornamentais, o 34 puošyba papildyta šriftu (inicialais, data, prasminiu tekstu). Klaipedos krašto delmonai tiriami Baltijos regiono liaudies kostiumo (estiškos - 90 vnt., suomiškos - 64 vnt., švediš-

ir techniniai piešiniai, atlikti Emili fon Walterstorff , saugomi Šiaurès šalių muziejaus archyvuose (Stokholmas, Švedija).

Carl Anders Dahlström (1806-1869). Folkdräkter från Rättvik och Leksand, Dalarna, Sverige. Plansch ur Svenska folkets seder, bruk och klädedrägter (1863) tecknad av Carl Anders Dahlström.

7 Interviu 2013 m. rugsèjo mèn.

8 http://www.vads.ac.uk/collections/POCKETS

9 http://www.vads.ac.uk/collections/POCKETS - Aukštuomenės kišenių kolekcijų nuotrauku programa. Programos vadovė Barbara Burman. 
kos -85 vnt., norvegiškos -62 vnt.) kišenių ir muziejuose išsaugotų įvairių tautu aukštuomenès aksesuarų (70 vnt.) kontekste. Liaudiškos kišenès siūtos iš įvairių puošnių ir brangių medžiagų (vilnos, aksomo, satino, kartūno, lino). Pačios paprasčiausios pasiūtos iš kitai kostiumo daliai (sijonui, liemenei) skirto audinio ir sudaro kostiumo vientisumo įspūdị. Tokių kišeniu įvairove pasižymi Suomijos (Etelä-Pohjanmaa - Akaan, Jurvan, Lappeen, Karijoen ir Isojoen; Etelä-Savo Puulavesi) bei Estijos (Saaremaa, Veruma, Hyjuma, Lenema) regionai. Kišenès buvo siuvamos ne tik iš naujų medžiagu atraižų, bet ir iš senų drabužiu dekoruotu (siuvinètų) dalių (marškinių rankovių, kepuraičių, prijuosčių). Taip puošni audinio skiautė buvo dar kartą kūrybiškai panaudojama sukuriant praktišką kostiumo detalę. Tokių kišenių išlikę Suomijos (Suomen kansallismuseo) bei Estijos (Rahva, Pärnu) muziejuose. Didžioji dauguma kišenių buvo specialiai siuvamos ir dekoruojamos.

\section{Kišenių (delmonų) dekoravimas}

Tekstilè ornamentuojama įvairiais būdais: susiuvant skirtingų audinių skiautes; užsiuvant iškirptas tekstilines detales ant pasirinkto audinio (pagrindo); siuvinejjant jau išaustą audinị; išrenkant raštus audimo proceso metu. Visais šiais būdais buvo ornamentuojamos ir tautinio kostiumo kišenès. Tame pačiame rankdarbyje buvo derinami skirtingų spalvų bei raštu (languoti, dryžuoti, marginti) audiniai ir sudaromos spalvinių bei toninių audinio skiaučiu geometrinės kompozicijos (žr. 1 lentelę).

Skiautinio siuvimas. Iš skiaučių sukurtos dviejų rūšiu liaudiškos kišenès. Vieną grupę sudare iš trikampių (Suomija - Antrea, Sippola ir Luumäke; Švedija Västmanland) bei keturkampių (Estija - Valgama, Saaremaa, Švedija - Närke) vienspalvio audinio skiaučiu pasiūtos didelès kišenès. Kitą - iš raštuotų pirktiniu medvilnès stačiakampių susiūti maišeliai (Suomija - Pohjois-Karjala, Polvijärvi, Saarivaara; Estija - Viljandi, Tartuma, Raplama). Iš vienspalvių bei margintų audinių atraižų sudarytoms kompozicijoms papildomo dekoro (siuvinėjimo) nebereikejjo. Skirtingo audinio vidurinè juosta, kaip kišenès dekoras, buvo naudojama Suomijos (Savo, Kainuu, Häme, Pohjanmaa), Estijos (Viljandi) regionuose. Jau minètos spalvinių bei toninių audinio skiaučiu geometrinès kompozicijos (siūtos skiautinių būdu) - populiarus švediškų bei suomiškų kišenių siuvimo būdas. Siuvant audinių atraižos komponuotos įvairiai. Vienos sudaro griežtas simetriškas kompozicijas, kitos susiūtos be jokių konkrečių taisykliu, matyt, vadovautasi paties gamintojo vaizduote. Kišenès tiesiog atspindi tai, ką diktavo regioninès mados tendencijos, siuvimo meistriškumas, turimų medžiagu resursai bei populiarumas. Kartais kompoziciją sudarančios skiautės dar buvo 
dekoruojamos siuvinèjimu. Toks pavyzdys, išlikęs užfiksuotas fotografijoje, saugomas archyvuose ${ }^{10}$ ir paskelbtas publikacijose ${ }^{11}$. Tai vienintelis žinomas iš skiaučių susiūtas ir dekoruotas Klaipèdos krašto delmonas (žr. 1 lentelę. Klaipédos kraštas).

Aukštuomenėje iš skiautinių siūtos kišenès buvo populiarios Škotijoje, Jungtinèje Karalystejje, tarp ỉ Ameriką emigravusių Anglijos piliečių. Jos siūtos iš skiautinių rankdarbiams būdingų margų (gèlètų, languotų, dryžuotų) medvilninių ir plonų vilnonių audinių. Trikampès arba stačiakampès audinių atraižos dèliotos laisvai ar komponuotos simetriškai, sukuriant geometrines kompozicijas. Aukštuomenès bei liaudiškų šios rūšies kišenių ornamentika panaši. Ornamentų variantų i̇vairovę riboja siuvimo technologija. Nors skiriasi kišenių konstrukcija: aukštuomenès kišenių ịpjova rankai įkišti vertikali, o liaudišku kišenių - horizontali, tačiau panašios dekoro geometrinès kompozicijos (žr. 1 lentelę).

Aplikavimas. Ornamento sudarymas ant pagrindo užsiuvant ryškių spalvų audinio (dažniausiai geometrines) detales būdingas Švedijos (Småland, Härjedalen, Ångermanland, Hälsingland), Suomijos (Etelä-Pohjanmaa, Vehkalahti, Helsingin Pitäjä) ir Estijos (Saaremaa, Hiiumaa, Muhumaa, Anseküla) liaudiškoms kišenèms (žr. 2 lentelę). Šia technika kišenės dekoruotos kukliais pavieniais ornamentais ir sudètingomis simetriškomis kompozicijomis. Švediškos (Dalarna) aplikacijomis dekoruotos kišenės dar buvo puošiamos ir siuvinèjimu (žr. 1 pav.). Spalvoto audinio figūros daigstomos dekoratyvinèmis kontrastingo storo siūlo siūlèmis (juostiniu ornamentu) arba geometriniais elementais (kryželis, apskritimas, rombas). Kišenę sudaro dekoruota viršutinè priekinė dalis ir kišenėlè, pamušalas ir nugarinė dalis. Atskirų dalių tarpusavio koreliacija sukuria specifines dekoro charakteristikas. Kišenės spalvinė gama dažniausiai buvo užbaigiama kraštus apsiuvant kontrastingos spalvos aksomo, vilnos, šilko, medvilnès ar kartūno juostele (vienspalve, marga, languota ar dryžuota). Dažniausiai kantuota raudonos spalvos audinio juostele (švediškos - $40 \%$, estiškos - $30 \%$, klaipédietiškos $-20 \%$, suomiškos $-10 \%$ visų juostelèmis apsiūtų kišenių), suteikiant rankdarbiui iškilmingumo ir išryškinant jo dydį bei formą. Toks kišenės kraštu užbaigimas - liaudiškų kišeniu dekoravimo bruožas. Apvadu juostelès buvo naudojamos tiek puošyboje, tiek konstruojant kišenes (tarpusavyje jungiant atskiras detales). Dažniausiai tokias juosteles nusipirkdavo, bet kai kurias pasigamindavo iš namuose austų medžiagų, kurias kirpdavo įstrižai arba pusiau ịstrižai audinio.

10 [41144] Königsberg (Pr.), Prūsijos muziejus (Prussia Museum).

11 Tamošaitis 1979 - Antanas and Anastasia Tamošaitis. Lithuanian national costume. Lithuanian folk art institute. Toronto, Canada, 200.

Zuban 1933 - Zuban, G. Deutsche Volkstrachten - Eine Sammlung deutscher Trachtenbilder (1933, 39, Scan, Fraktur). 
1 lentelè

Skiautinių technika dekoruotų kišenių geometrinès kompozicijos

\begin{tabular}{|c|c|c|c|c|c|}
\hline \multicolumn{6}{|c|}{ SKIAUTINIU TECHIKA } \\
\hline
\end{tabular}

Aplikavimu dekoruotų kišenių geometrinès kompozicijos

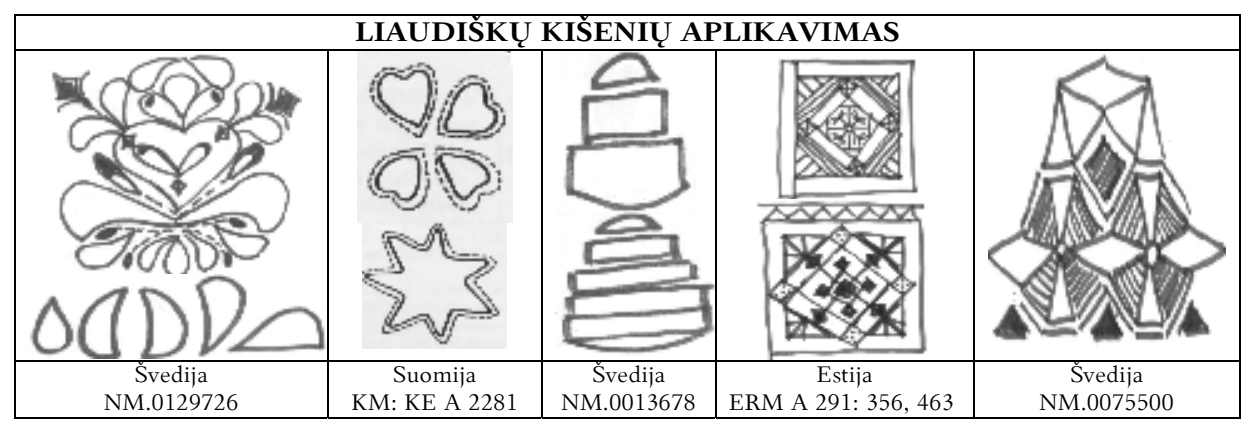

12 Königsberg (Pr.), Prūsijos muziejus (Prussia-Museum). Tasche mit Wollstickerei aus dem Memelland. Publikuota: Tamošaitis 1979 - Antanas and Anastasia Tamošaitis. Lithuanian national costume. Lithuanian folk art institute. Toronto, Canada, 200.

13 Škotijos nacionalinis muziejus (National Museums of Scotland). http://www.vads.ac.uk/

14 Dailès muziejus Bostone (Museum of Fine Arts, Boston) 50.3126.

15 Winterthur muziejus (Winterthur Museum). Anglija, Jungtinė Karalystė, Europa (England, United Kingdom, Europe). 1960.0249.

16 http://www.pinterest.com/pin/462744930432442015/ 

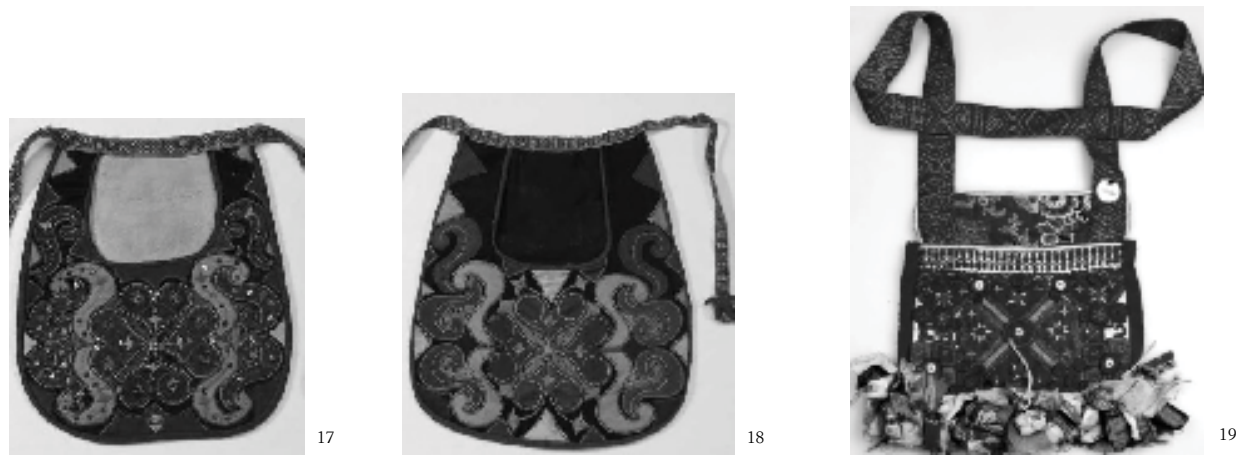

1 pav. Aplikavimu dekoruotų kišenių siuvinejjimo pavyzdžiai (Švedija, Dalarna)

Siuvinèjimas. Populiariausias liaudišku kišenių dekoravimo būdas - siuvinèjimas. Ornamentas dažniausia buvo siuvinèjamas ant tamsaus fono ryškių spalvų siūlais. Siuvinėjimu dekoruoti priekiniai kišenių paviršiai siūti iš tamsių, standžių audinių (vilnos, aksomo). Siuvinejjimas ant juodos spalvos audinio būdingas visoms Europos tautoms. Dažnai aptinkamas tamsiai mèlynas, žalias, rudas kišenès pagrindas, o Švedijoje populiarūs siuvinėjimai ant raudono vilnonio audinio. Dažniausiai siuvinèta spalvingais vienos rūšies (Švedijoje, Suomijoje, Norvegijoje) vilnoniais ar šilkiniais siūlais įvairiais dygsniais (grandininiu, kilpiniu, zigzago, kryželio ir kt.). Klaipėdos krašte viename rankdarbyje derinti skirtingų rūšių ir skirtingų spalvų siūlai, ornamentai siuvinėti kelių rūšių dygsniais.

Aukštuomenès kišenès siūtos iš šviesių (medvilnè, linas), dažnai prabangių (šilkas) audinių ir siuvinètos vilnoniais, šilkiniais, medvilniniais (viename rankdarbyje vienos rūšies) siūlais. Dažniausiai siuvinėta viena technika (kryželiu, grandinèle), kartais naudota keletas siuvinėjimo būdų (grandinèlè ir pildymo technika). Populiariausios augalinių ornamentų ir paukščių kompozicijos, pasitaiko stilizuotų žmogaus ir gyvūno figūrèlių.

Liaudiškų kišenių siuvinètas ornamentas dar būdavo papildomas stiklo karoliukais (Klaipėdos krašte) ar dekoratyvinèmis siūlèmis prisiūtais nedideliais apskritais veidrodèliais (Suomijoje: Iitti, Jaala, Nastola, Varsinais Suomi). Estijoje skirtingų spalvų karoliukais buvo siuvinejamas ne tik ornamentas, bet ir visas priekinis kišenès paviršius. Suomijoje bei Estijoje ornamentuojant naudoti ir įvairūs tekstilinès galanterijos dirbiniai (juostelès, kaspinai, virvutės) bei sagos (žr. 3 lentelę).

\footnotetext{
171879 m. NM.0023972 Šiaurès muziejus (Nordiska museet).

$181880 \mathrm{~m}$. NM.0026256A Šiaurès muziejus (Nordiska museet).

19 GM.013421 Glomdals muziejus (Glomdalsmuseet).
} 


\section{Papildomas siuvinètų kišenių dekoravimas (karoliukai, veidrodèliai, juostelès)}

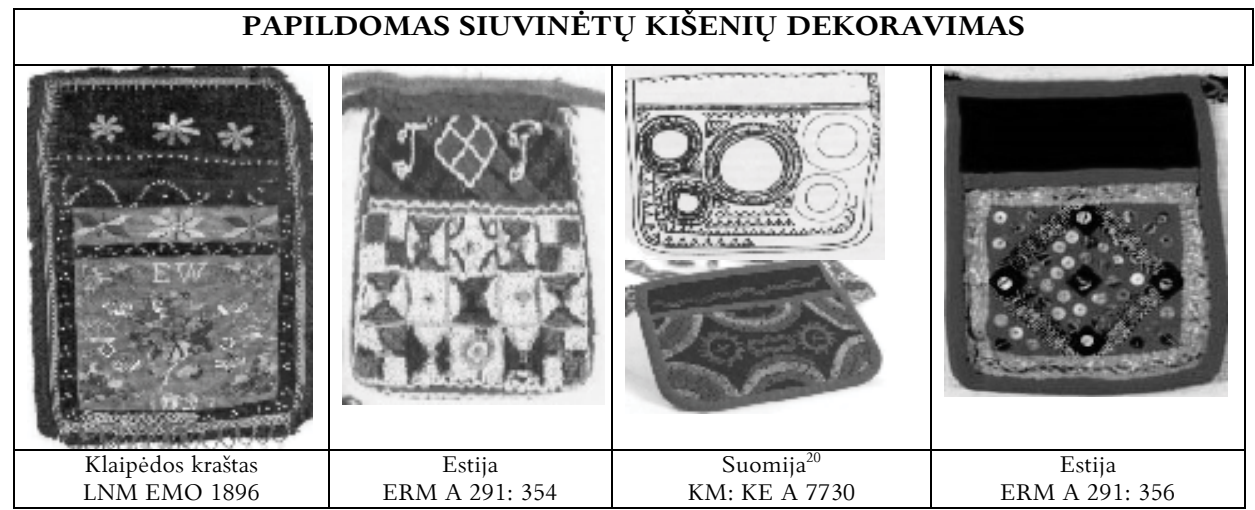

\section{Kišenių (delmonų) raštų siužetai}

Liaudies mene pagrindinè dekoravimo priemonè - ornamentas. Ornamentai (raštai) sudaromi įvairiai komponuojant atskirus elementus. Raštus sudarantys elementai būna geometriniai (kvadratas, rombas, apskritimas ir kt.) arba stilizuoti siužetiniai (augaliniai, gyvūniniai). Geometriniai ornamentai universalūs. Atskiros geometrinès figūros gali būti siuvinejjamos kaip pagrindinis motyvas arba kaip sudètinès kompozicijos dalis ir bendrame dekoro kontekste igyti skirtingas prasmes.

Siužetinio ornamento motyvai. Tiriamų kišenių dekore galima išskirti siužetinių ornamentų motyvus, kurie įvairiai komponuojami plokštumoje. Didžiausią grupę sudaro stilizuotos bei natūralistinès asimetrinès gèlių kompozicijos. Gèlių žiedai ir lapai - vieni populiariausių ornamento motyvų. I vieną kompoziciją jungiami vienos rūšies (rožių) ar skirtingų gèlių žiedai, pumpurai, lapai. Stilizuotuc ar natūralistinių gèlių (simetrinès bei asimetrinès) kompozicijos (puokštès), dažniausiai užimančios centrinę kišenès dalị, būna papildomos mažesniais ornamentais. Labiausiai paplitę siužetiniai ornamentai: širdelè; augalas (medis, krūmas, gèlè); žvaigždè, segmentinis žiedas ir vainikas; paukštis ir kiti gyvūnai; karūna bei ịvairūs archetipiniai (kryžius, kvadratas, rombas, apskritimas) bei krikščioniški (kryžius, inkaras) ženklai. İvairių ženklų (motyvų), aptinkamų liaudies (ir profesionaliojo) meno dekore, simbolinès prasmès mokslininkų gana plačiai nagrinètos. Šiame straipsnyje paminèsime tik tas, kurias, autorès nuomone, tiriamų kišenių gamintojai galejo būti perèmę iš tautosakos ir krikščioniškos

20 E. M. 2012 m. 
dailès. Išraiškingi simbolines prasmes turèję ženklai liaudies meistru galèjo būti naudojami ir tik estetiniais sumetimais. Remiantis „Naujajame simbolių žodyne“ (Biedermann 2002) pateiktomis bei iki šių dienų išlikusiomis ženklų prasmémis, išskirtinos šiu labiausiai paplitusių siužetinių ornamentu prasmės: širdele meilès linkejjimo, švelnumo ir palankumo ženklas; augalas - vyriškojo prado ir stebuklingos žemès galios vaisius (Gimbutienė 1994); žvaigždè - siuvinètos įvairios daugiakampès žvaigždès (penkių-aštuonių kampų) kaip dangaus skliausto simbolinės šviẽsos, nors kiekviena žvaigždès forma turi savo prasmių aiškinimo istoriją ${ }^{21}$; segmentinis žiedas - jaunystės simbolis, gyvasties galia bei gyvenimo džiaugsmas, pasibaigusi žiema ir pergale prieš mirtį, žemiško gyvenimo trapumas ir laikinumas; vainikas - pergalè prieš tamsiąsias jègas ir nuodèmes, žemiškas džiaugsmas ir amžinasis gyvenimas, prisikèlimas ir džiaugsmas; paukštis - žmogaus sielos, minties galios, kūrybiškumo, Šventosios Dvasios simbolis; karūnakarališkumo, perèjimo į naują egzistencijos pakopą žymèjimas. Šių motyvų siluetai aptinkami ir XVIII-XIX a. aukštuomenès kišenių dekoravime. Ju panašumą su liaudies siuvinejjimais iš dalies lèmé bendroji mados tendencija, nepalikusi nuošalyje ir kaimo gyventojų, kurie madingos tekstilès pavyzdžius matė miesto ir dvaro aplinkoje. Panagrinékime atskirų motyvų paplitimą tautinių kostiumų kišenių dekoravime ir jų sąsajas su aukštuomenès kišenių dekoru.

Širdelès motyvas aptinkamas įvairiuose klaipedietiškų bei švediškų rankdarbių ornamentuose (žr. 1 diagramą). Daugiausia pavyzdžių (54 vnt.) surasta švediškose kišenèse. Tai sudaro 77 \% visu dekoruotų švediškų kišenių. Keliose iš ju širdele komponuota kišenès centre kaip savarankiškas ornamentas (Hälsingland, Dalarna - Älvdalen). Dauguma kitų kompozicijų sudarytos iš keturių širdelių (primena gèlès žiedą), jas komponuojant su papildomais elementais. Šitoks komponavimas yra būdingas Dalarnos (Dalarna: Leksand ir Rättvik) regionui. Autorei pavyko rasti daugiau kaip 40 tokių kompozicinių variantų. Dažnai į vieną kompoziciją jungiamos keturios širdelès. Lietuvininkių delmonuose širdelès motyvas naudojamas kaip papildomas savarankiškas elementas kompozicijos erdvei užpildyti arba kaip sudètinio augalinio ornamento elementas, simbolizuojantis pačią žemę. Kaip augalo ar medžio elementas širdelè siuvinèta ir Švedijoje (Gästrikland). Kitų tautų kišenių dekore širdelès motyvas gana retas, tačiau šis elementas kaip kompozicijos dalis arba savarankiškas akcentas buvo siuvinejjamas aukštuomenès kišenèse (žr. 4 lentelę).

21 Septynkampe žvaigždè. Krikščionybẻje heptagrama simbolizuoja tobulumą (Dievo tobulumą) ir septynias pasaulio kūrimo dienas. Tai tradicinis blogị nuvarantis simbolis.

Betliejaus žvaigžde, arba bibline žvaigžde, - pilnavidurè plokščia žvaigždè, kurią sudarantys trikampiai susilieję (Lietuvoje žinoma kaip Trijų karaliu žvaigždè). 


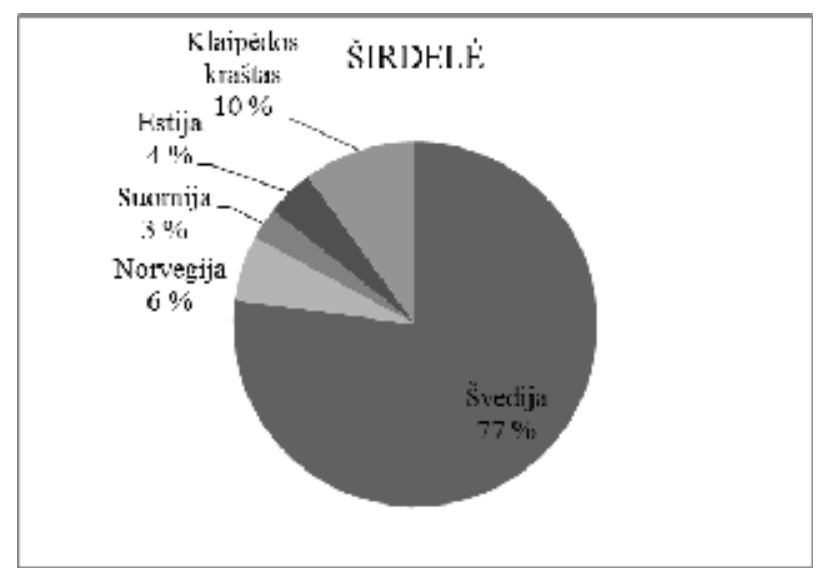

1 diagrama. Ornamento motyvo paplitimas. Širdelè

\section{Ornamento motyvai. Širdelè}

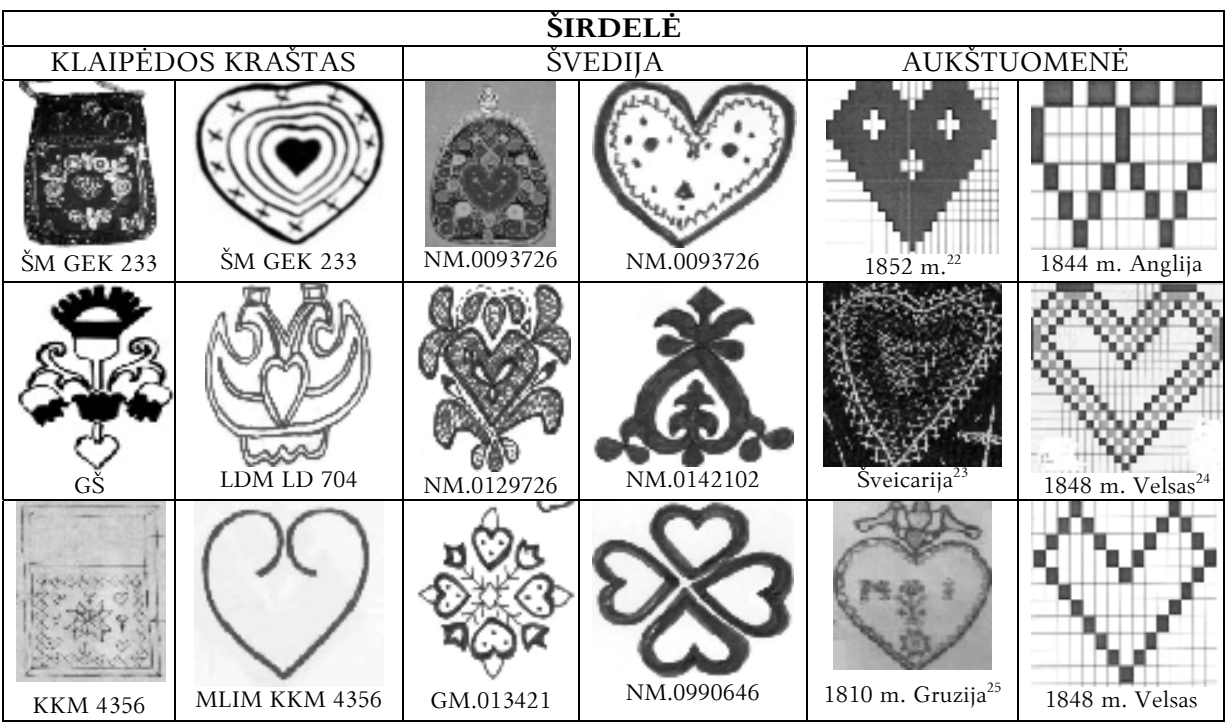

Augalas (gèlè, medis). Šis motyvas yra išplètotas daugelio tautų liaudies mene, dažnai aptinkamas ir tautinio kostiumo kišenių dekoravime (žr. 2 diagramą). Siuvinejamos ịvairios jo atmainos nuo primityvaus sąlyginio (stiebelio su

22 O. Box 5353 Takoma Park, MD 20912 301-589-5834 Lnbrown@granitepail.com 1852. Pensilvanija Šiaurès Amerikoje (olandu).

23 Winterthur Museum Object Number: 2006.0011.001 Vintertūras - miestas Šveicarijos šiaurèje, Ciuricho kantone.

24 Amgueddfa Cymru/ Nacionalinis Velso muziejus (National Museum Wales).

${ }_{25} 1810$ m. Gruzijos rankdarbis. https://www.pinterest.com/pin/32932641001557696/ 


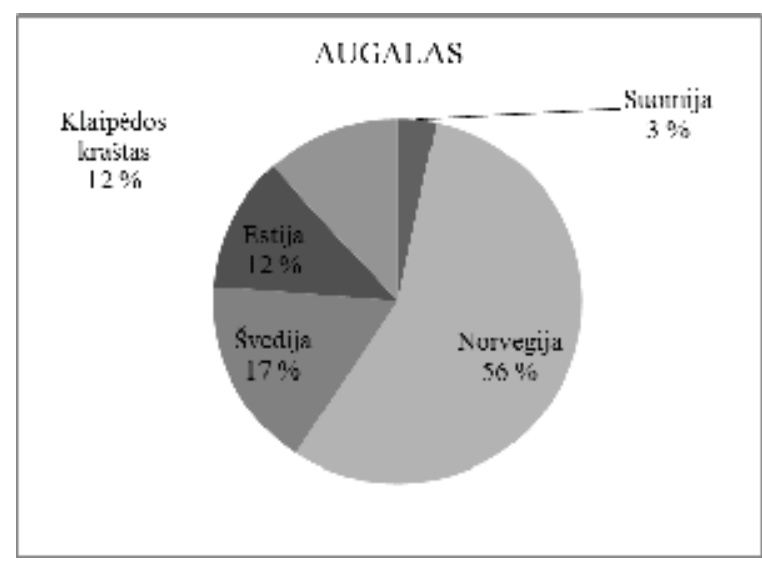

2 diagrama. Ornamento motyvo paplitimas. Augalas

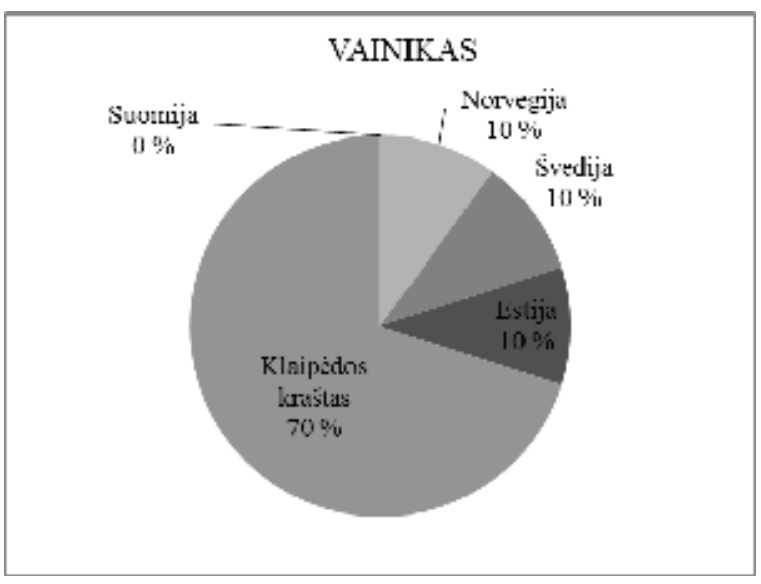

3 diagrama. Ornamento motyvo paplitimas. Vainikas stilizuotu žiedu) vaizdavimo ar žydinčios gèlès vazonèlyje iki sudètingu augalinio ir geometrinio ornamento jungčių, papildytų paukščiu motyvais. Šis siužetas dažnai siuvinėjamas kišenès centre kaip pagrindinis dekoro elementas. Kišenès pakraščiai ir kampai būna užpildomi ištisiniu geometriniu (juostiniu) ornamentu arba atskirais kitų savarankiškų (mažesnių) siužetinių motyvų ar šrifto elementais. Tokiomis simetriškomis kompozicijomis papuoštos lietuviškos (7 vnt.) ir estiškos (7 vnt.) kišenès. Daugiausia augalinių kompoziciju (33 vnt.) aptinkama norvegiškose kišenèse (Oppland - Valdres, More, Romsdal; Sor - Trondelag, Telemark). Norvegiškos medžio kompozicijos kartais papildomos inicialais ar data. Geometriniuz elementų ar paukščiu motyvu nepastebèta. Ivvairios medžio formos buvo labai populiarios aukštuomenès rankdarbiuose. Net 50 \% visų tiriamų pavyzdžių tai buvo pagrindinė augalinio ornamento kompozicija, užpildanti visą siuvinėjamą paviršių. Kai kišenè dekoruojama smulkių siužetinių ornamentų komponavimu, nedidelių medžiu variacijos yra siuvinėjamos net keletą kartų. Dauguma tiriamų (liaudies bei aukštuomenès rankdarbių) kompozicijų sudarytos iš tradiciškai nusistovejjusių trijų dalių: pagrindo (puodynès, vazelès, postamento), stiebo su šakomis ir lapijos su pumpurais, žiedais (kartais ir paukščiais). Stiebo ar pagrindo vietoje dažnai komponuojamas širdelès motyvas (žr. 4 ir 5 lenteles). 
Ornamento motyvai. Augalas

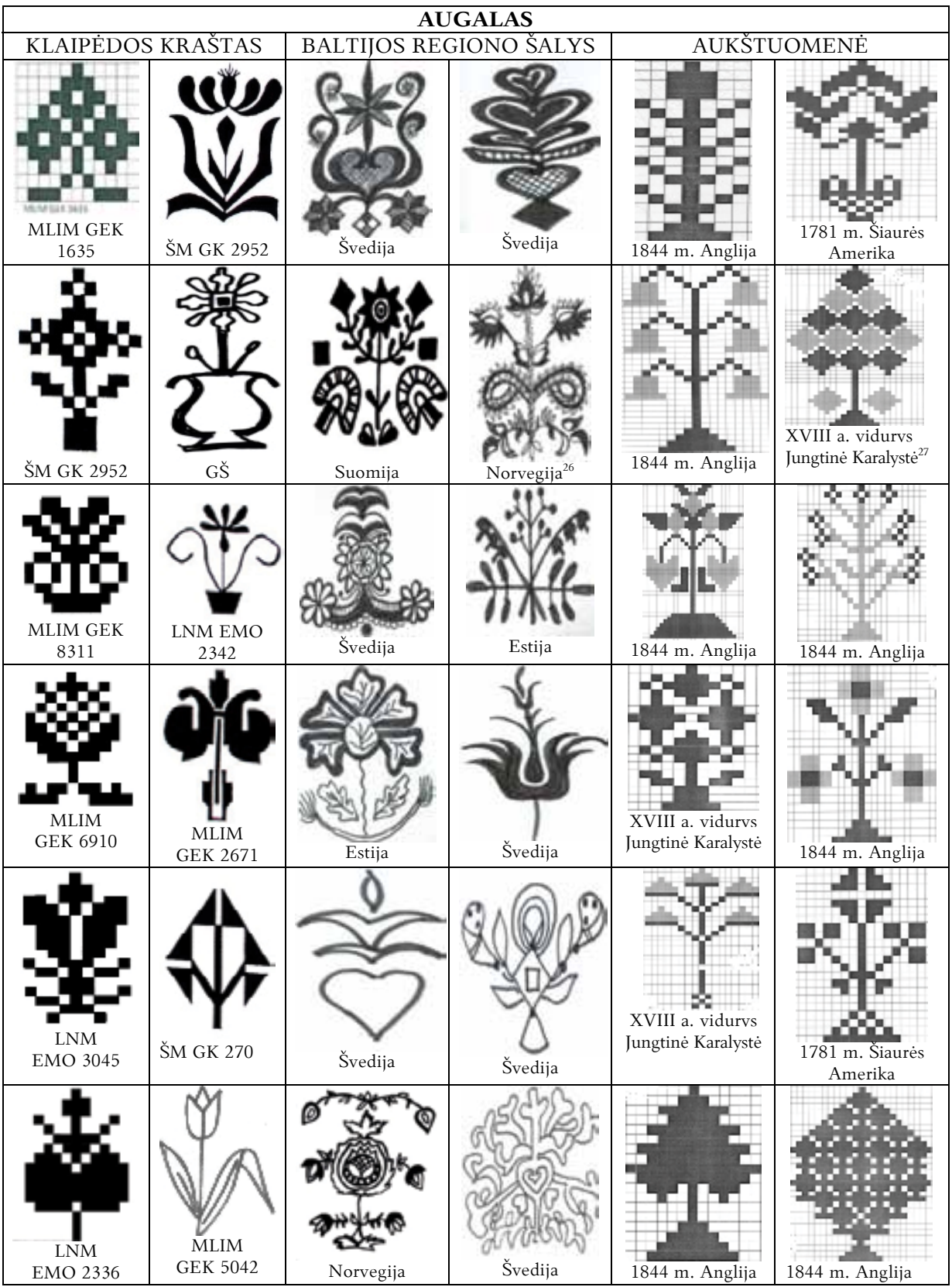

26 Duran 2012 - Laila Duran. Scandinavian Folklore II. Duran Publishing AB, Sweden, 89.

27 Nacionalinis istorijos muziejus. http://www.twitpic.com/2wxblr. Llandysul, Jungtinè Karalystè, XVIII a. vidurys. 
Gèlès žiedo motyvas. Lietuvininkių delmonų puošyboje gèlès motyvas labai dažnas. Iš 64 dekoruotų delmonu asimetriškos gèlių kompozicijos išsiuvinètos net 22. Iš ju 14 delmonu papuošti rožiu žiedais. Siuvinèjamos natūralistinès gèlių puokštės ir stilizuoti pavieniai žiedai, žydinčios šakelès. Pasitaiko, kai visas paviršius išpuoštas gèliu kompozicijomis nepaliekant net fono spalvos (ŠM GEK 3728, LNM EMO 2331). Kitų tautų kišenių kontekste išsiskiria vainiko motyvas (žr. 3 diagramą), apjuosiantis prasminį tekstą, šriftą ar siužetinị elementą. Vainiko simboliką ${ }^{28}$ papildo dažni pavienių stilizuotų žiedų ir segmentinių žvaigždžių elementai, kurių gausu ir aukštuomenės kišenių dekore. Žiedai, apskritimai, žvaigždès siuvinẻjami kaip pagrindiniai ir kaip papildomi kompozicijos elementai. Gèliu puokštėse ir vainikuose tarp žiedų komponuojami lapai ir šakelès sukuria sodrią augalinę kompoziciją, kuri dažniausiai užpildo didžiausią siuvinėjamo paviršiaus dalị. Tokios kompozicijos dažnos klaipedietiškų, švediškų, norvegiškų rankdarbių puošyboje (žr. 6 lentelę).

6 lentelè

\section{Ornamento motyvai. Žiedai, lapai, vainikai}

\begin{tabular}{|c|c|c|c|c|c|}
\hline \multicolumn{6}{|c|}{ ŻIEDAI, LAPAI, VAINIKAI } \\
\hline KLAIPĖD & S KRAŚTAS & BALTIJOS RE & DNO ŚALYS & AUK & JOMENE் \\
\hline AdM & $\begin{array}{c}\text { LNM } \\
\text { EMO } 2342\end{array}$ & $\begin{array}{c}\text { Estija } \\
\text { ERM A 509: } 5620\end{array}$ & & $\begin{array}{c}1740-1770 \mathrm{~m} . \\
\mathrm{JAV}^{30}\end{array}$ & $\begin{array}{l}1750-1775 \mathrm{~m} . \\
\text { Jungtinès Valstijos }\end{array}$ \\
\hline 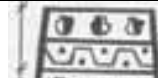 & & & & & \\
\hline ŠM GEK 236 & PR & $\begin{array}{l}\text { Svedila } \\
\text { NM.0026256A-E }\end{array}$ & Nr. 89762 & 1958.2325 & $\begin{array}{l}1740-1775 \mathrm{~m} . \\
1958.1758\end{array}$ \\
\hline Q 4 क 4 & & & & & \\
\hline $\begin{array}{c}\text { MLIM } \\
\text { GEK1962 }\end{array}$ & $\begin{array}{l}\text { MLIM } \\
\text { GEK1962 }\end{array}$ & $\begin{array}{c}\text { Švedija } \\
\text { NM.0109879I }\end{array}$ & $\begin{array}{c}\text { Švedija } \\
\text { NM.0109879 }\end{array}$ & $\begin{array}{c}1750-1775 \mathrm{~m} . \\
\text { Jungtines } \\
\text { Valstijos }\end{array}$ & $\begin{array}{c}1780-1840 \mathrm{~m} . \\
1966.1126\end{array}$ \\
\hline
\end{tabular}

28 Vainikas tapatinamas su apskritimu, begalybe, judejjimu, gyvybe.

29 Duran 2012 - Laila Duran. Scandinavian Folklore II. Duran Publishing AB, Sweden. Autors: Laila Duran, Swedish and Sami folk costumes; Anne Kristin Moe, Norwegian Bunads, 31.

30 Karališkasis Alberto muziejus ir galerija (Royal Albert Museum and Art Gallery), EXEMS/382/2006.

31 Jungtinès Valstijos, Šiaurès Amerika. 1954.0055.001.

321844 m. Švedija. Varmland Dalby piešinio Nr. 89762. 


ŽIEDAI, LAPAI, VAINIKAI

Stilizuoti augaliniai motyvai dažnai jungiami į girliandas, kurios ịrėmina centrinį elementą, akcentuoja rankdarbio kampus, viršutinę ar apatinę kraštines. Komponuojami žiedai, lapai ir kitos stilizuotos augalų dalys.

Klaipėdos krašto ir aukštuomenès kišenių dekore pasitaiko gèlių puokštės krepšelyje siužetas. Toki pavyzdi iš Šilutès rajono Kukorių kaimo (Saugų seniūnija) turime išsaugotą Lietuvos nacionaliniame muziejuje (LNM). Nors išlikęs tik vienas delmonas, puoštas tokia kompozicija, tačiau siuvinètos (ir ant audinio tapytos) gèlių puokštės krepšelyje motyvas liaudiškuose rankdarbiuose gana dažnas. Klaipėdos krašte juo puoštos staltiesès, staltiesèlès, pagalvèlès, sieniniai kilimèliai. Siuvinèta ne tik nuo darbų laisvomis valandèlèmis savo gimtuosiuose namuose (Klaipèdos krašte), bet ir gūdžioje Sibiro tremtyje (Irkutske). Komponuotos vienos rūšies (rožès, našlaitès) arba įvairių gèlių puokštès. Nuo XVIII a. iki pat XX a. pradžios šis siužetas (siuvinètas siūlais bei karoliukais) aukštuomenės damų rankdarbiuose aptinkamas Vokietijoje, Prancūzijoje, Belgijoje, Nyderlanduose. Senovinių siuvinejimo kompozicijų pavyzdžiai, pateikti internetinèse prieigose ${ }^{39}$, bei išlikę aukštuomenès rankdarbiai leidžia daryti prielaidą, kad publikuotais siuvinėjimo raštu piešiniais naudotasi ir aukštuomenèje, ir prastuomenèje. Šio motyvo populiarumą liudija rankdarbiu puošto gèlių stalelio dekoracija reprezentacinėje Klaipèdos krašto merginos, vilkinčios išeiginiais drabužiais, nuotraukoje (žr. 7 lentelę).

33 http://www.nordiskamuseet.se/en/node/2355

34 http://www.vads.ac.uk/collections/POCKETS

${ }_{35}$ Karališkasis Alberto muziejus ir galerija (Royal Albert Museum and Art Gallery), XEMS/382/2006.

36 http://lenasvalforshedin.se/2012/art-craft/colourful-embroidered-folk-costume-bagsunderbara-draktvaskor-till-folkdrakt-fran-dalarna/

37 Ten pat.

38 gnr/bnr 9.002. http://collections.vam.ac.uk/item/O78763/bag-unknown/

39 Prancūziški mazgai. Siuvinèjimo technikų, kompozicijų pavyzdžių svetainè. http://www. french-knots.com/embroidery-transfer-patterns-flowers-baskets-hearts-and-roses-oh-my/ 
Ornamento motyvai. Gẻlių puokštẻ krepšelyje

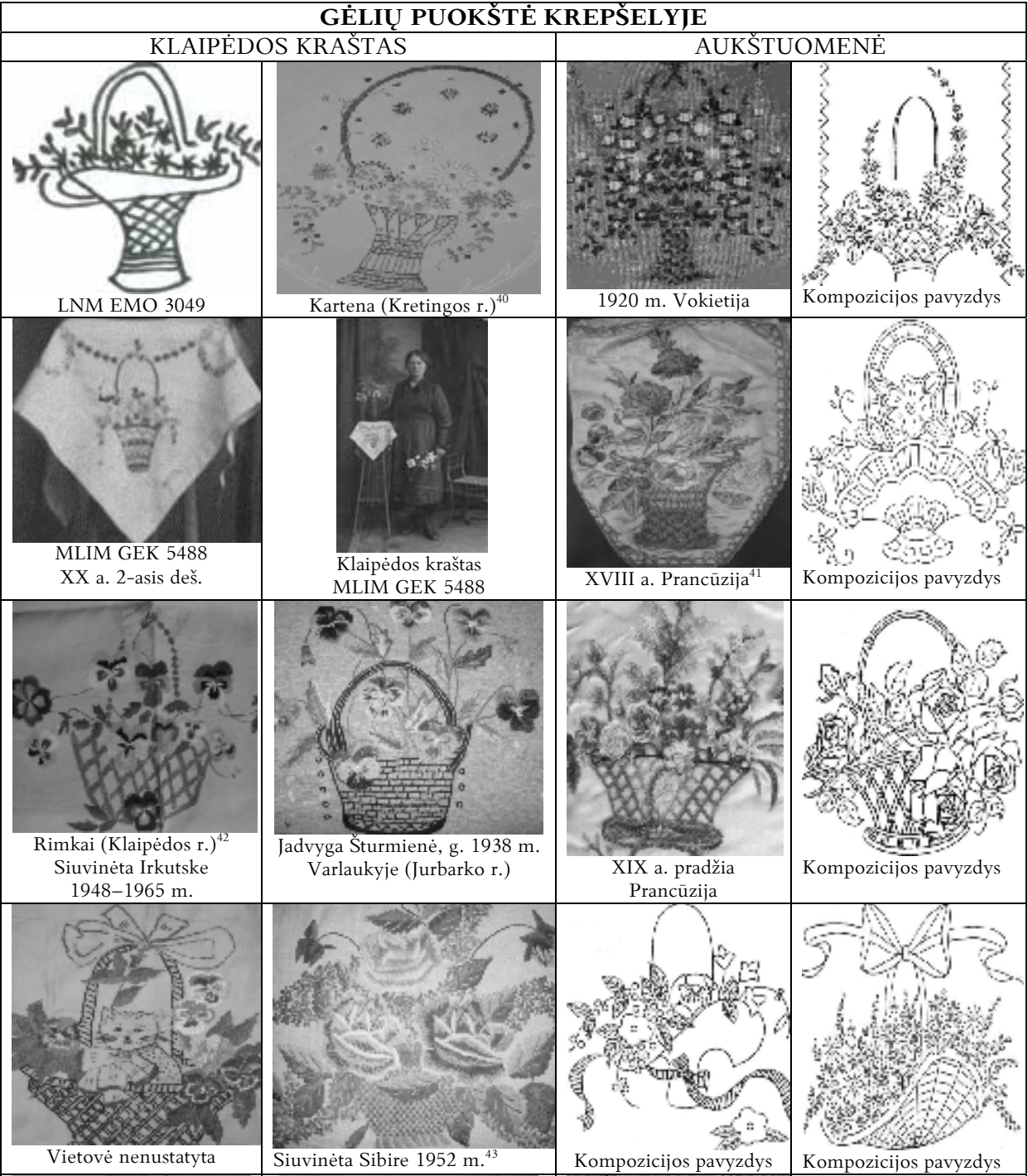

40 Justinos Daugienès, g. 1923 m., gyvenusios Kartenoje (Kretingos r.).

${ }^{41}$ http://eldisblog.com/post144423177/; http://www.ethnomuseum.ru/galerei chatelaine bag. антикварные напоясные мешочки. Aukštuomenès antikvariniai ties juosmeniu parišami maišeliai ir rankinès.

42 Onos Makaravičienès (1925-2009) staltiesè, siuvinèta tremtyje.

43 Jadvyga Šturmienè, g. 1938 m. Varlaukyje. Siuvinèta tremtyje Sibire. 


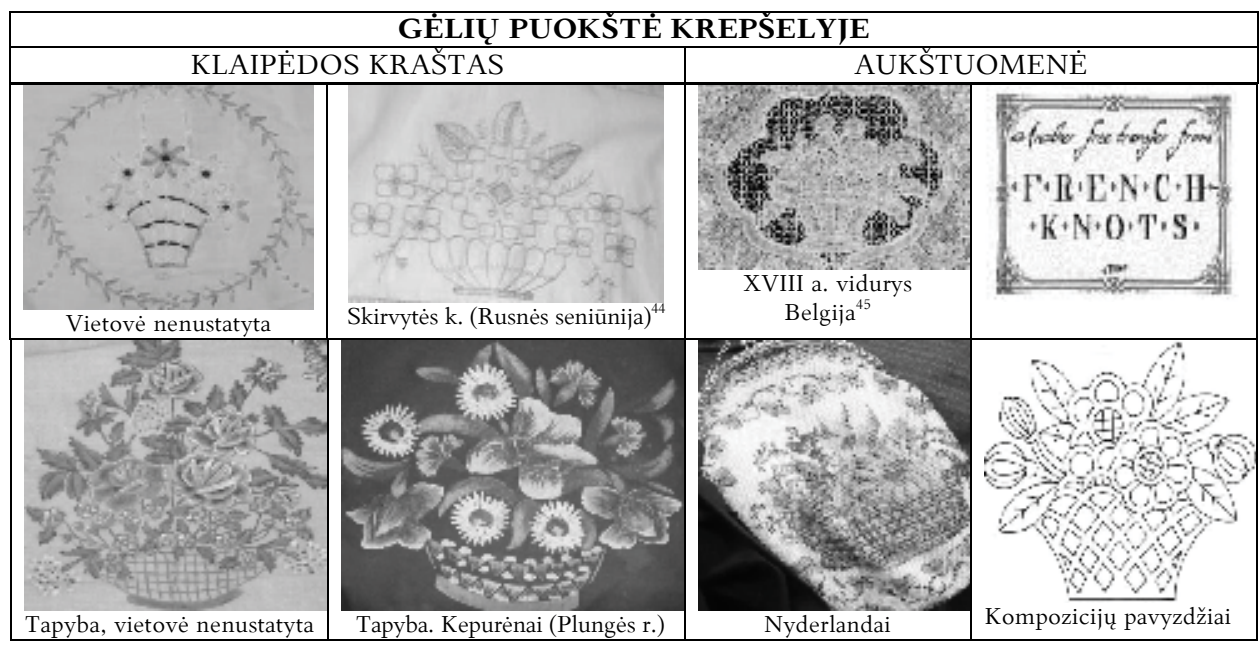

Karūnos motyvas. Nagrinėjant kišenių ornamentiką siužetiniu požiūriu, reikètu išskirti dar vieną grupę ornamentų - stilizuotas karūnas, kurios įvairiai (po vieną, dvi, šešias) komponuojamos penkiuose delmonuose. Didelè karūna, kaip centrinis akcentas, siuvinèta tarp (šalia) inicialų ir datos. Mažesnès karūnèlès, kaip kompoziciją papildantys elementai, kartu su archetipiniais ženklais, data ir inicialais komponuotos perimetru apie centrinį ornamentą. Po keletą stilizuotuc karūnų aptinkame Švedijos (Blekinge, Karlshamn; Härjedalen, Lillhärdal) bei aukštuomenès kišenėse. Kišenių dekore siuvinètos stilizuotos karūnos perteikia istorinių bajorų, grafų, didžiojo hercogo, senosios karaliaus karūnų formas ir sąlygiškai gali būti atpažịstamos (žr. 8 lentelę). Karūna - ne tik absoliučios valdžios, bet ir laisvès, šlovès, išskirtinès padėties simbolis. Karaliaus instituciją turi Švedija, Klaipėdos kraštas, kaip Rytų Prūsijos dalis, taip pat turèjo savo valdovą Prūsijos karalių Frydrichą Vilhelmą III, 1776-1840 m. valdžiusį Prūsiją. Karūna galèjo simbolizuoti ir Klaipèdos krašto laisvųjų valstiečių statusą.

Išskirtiniai lietuvininkių delmonų ornamentų motyvai. Lyginant lietuvininkių delmonų dekorą su kaimyninių tautų rankdarbiais pastebèta paukščių, vabzdžių, šunų, žmonių figūrèlių ir kitų siužetinių elementų (namas, kryžius, medis), nebūdingų kaimyninių tautu kišenių dekorui, tačiau aptinkamų aukštuomenès moterų dẻvėtų kišenių (rankinių) puošyboje. Lietuvių liaudies tekstilëje siužetinių zoomorfinių (gyvūninių) bei antropomorfinių (žmonių figūrèlių) ornamentų nèra daug. Didžiąją dalį sudaro paukščių motyvai, pasitai-

44 Kazio Banio privataus muziejaus eksponatas (pagalvės užvalkalas).

45 Viktorijos ir Alberto muziejus (Nr. T.50-1949). Briuselis, Belgija. XVIII a. vidurys, pinti nėriniai. http://www.rankdarbiunamai.lt/wp-content/uploads/2012/01/pintiner03.jpg 


\section{Ornamento motyvai. Karūna}

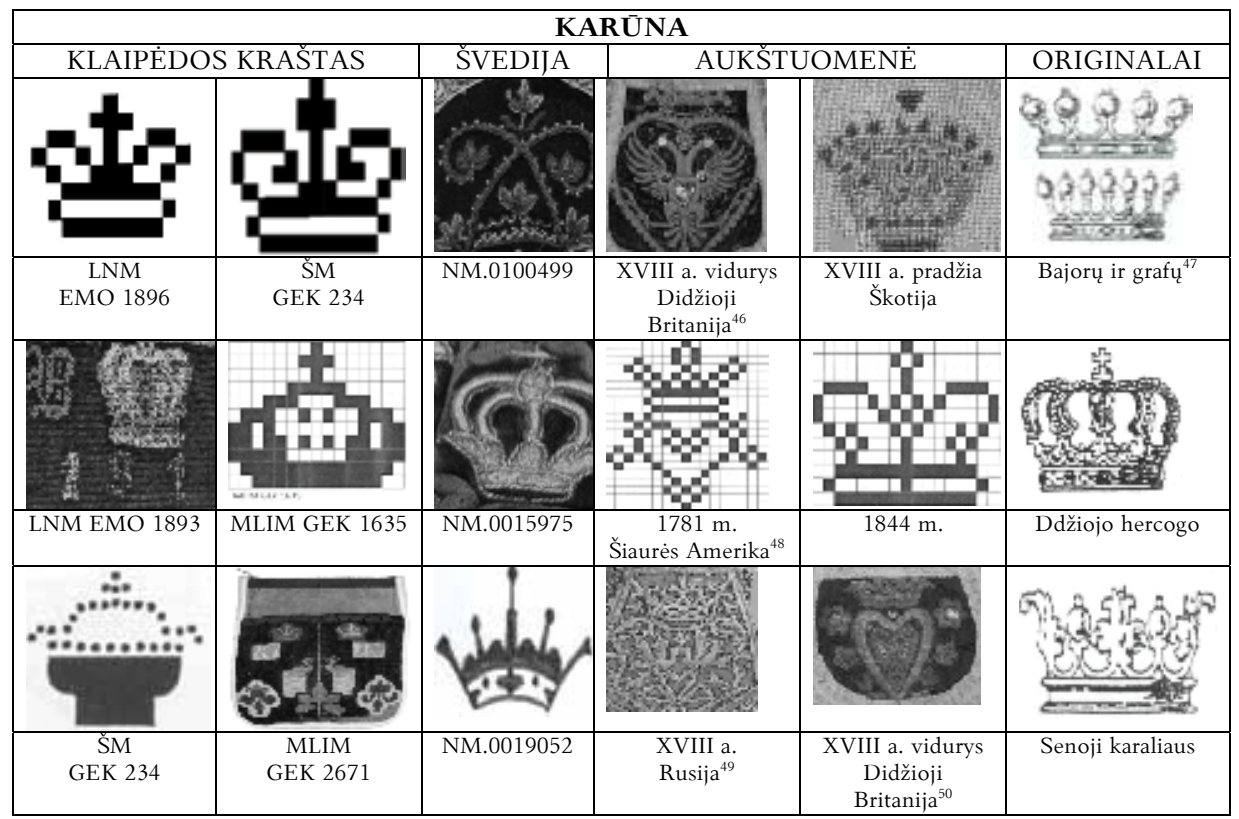

kantys įvairių buitinès tekstilès rankdarbių (staltiesių, sieninių kilimèlių, pagalvių užvalkalų) ir delmonų ornamentikoje. Keturkojai žinduoliai (šunys, elniai, briedžiai) ir įvairūs vabzdžiai (drugeliai, boružèlès ir kt.), išsiuvinèti ant lietuvininkių delmonų, atrodo gana egzotiškai ir siejasi su aukštuomenès kišenėmis (žr. 9 lentelę). Šie elementai lietuvininkių kišenėms suteikia žaismingumo. Išsiuvinèti nesilaikant griežtos simetrijos (intuityviai užpildant kompozicinę erdvę), jie atskleidžia esminị liaudies meno dekoro bruožą - žaismingą naivumą, laisvą pasirinktų elementų komponavimą plokštumoje siekiant perteikti kūrẻjo nuotaiką ar „papasakoti“ norimą siužetą. Tokios kompozicijos emociniu požiūriu labai iškalbingos ir primena vaikiškus piešinius. Impulsyvumas atsispindi ir elementu komponavime, ir spalviniuose sprendimuose.

46 Victoria and Albert Museum. 1437.1871 Didžioji Britanija. http://www.vam.ac.uk/page/t/thecollections/

47 Biedermann 2002 - Hans Biedermann. Naujasis simbolių žodynas. Vilnius: Mintis, 185.

48 Pennsylvania, Mid-Atlantic, United States, North America. 2013.0031.103.

49 Damų rankinès iš N. L. Šabelskos rinkinio (Дамские сумочки из собрания Н. Л. Шабельской). http://lj.rossia.org/users/dr_bogdanov/3504643.html.

50 Victoria and Albert Museum. 1438.187 Didžioji Britanija. http://www.vam.ac.uk/page/t/thecollections/ 


\section{Ornamento motyvai. Keturkojai žinduoliai. Vabzdžiai. Kiti siužetiniai elementai}

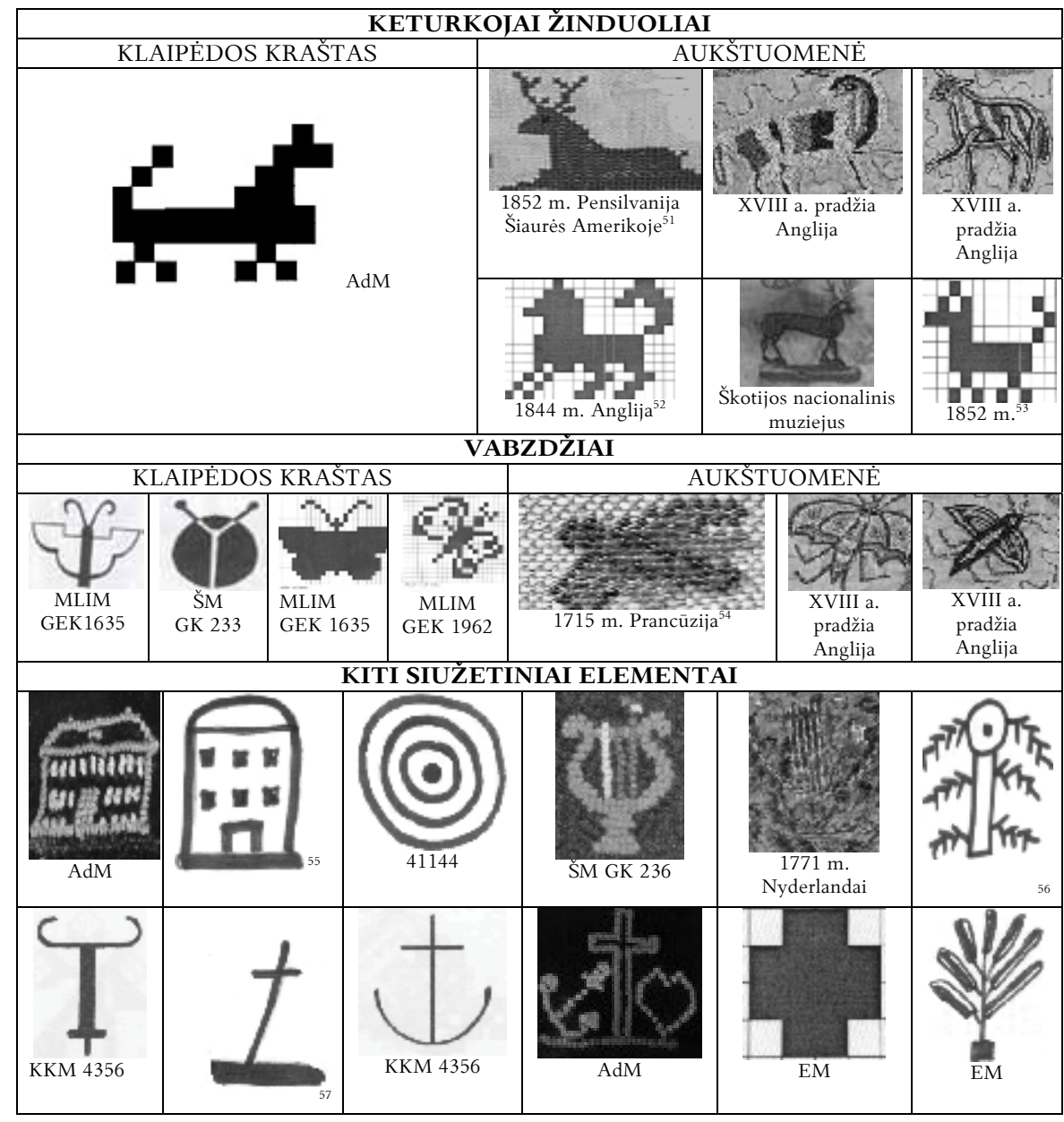

51 O. Box 5353 Takoma Park, MD 20912 301-589-5834 Lnbrown@granitepail.com 1852. Pensilvanija Šiaurès Amerikoje (olandu).

${ }^{52}$ Queen Victoria Period: $19^{\text {th }}$ century. Humphrey, Carol. 1984. English Samplers at the Fitzwilliam. Cambridge (Cambs.): The Fitzwilliam Museump. 38. Publ. No. 88 Accession: Object Number: T. 67-1938 England, production, country English, nationality.

53 O. Box 5353 Takoma Park, MD 20912 301-589-5834 Lnbrown@granitepail.com.

54 Dailess muziejus, Bostonas. http://www.metmuseum.org/collection/the-collection-online/search/230688?

55 Tamošaitis 1979 - Antanas and Anastasia Tamošaitis. Lithuanian national costume. Lithuanian folk art institute. Toronto, Canada, 200.

56 Tirolio liaudies meno muziejuje (Tiroler Volkskunstmuseum) Insbruke (Austrija), aplanke 25/ Ostpreussen (Rytprūsiai) saugomi dailininkès E. V. Korff 1941 m. perpiešti ir aprašyti Hugo Šojaus muziejuje saugoti tekstilès eksponatai. Perpiešti ir du delmonai, kurių likimas nežinomas. Fragmentas iš vieno delmono piešinio.

57 Tamošaitis 1979 - Antanas and Anastasia Tamošaitis. Lithuanian national costume. Lithuanian folk art institute. Toronto, Canada, 200. 
Prie išskirtinių lietuvininkių delmonų siužetinių motyvų priskirti stilizuoti paukščiai - dažniau aptinkamas elementas. Turime išsaugotus 8 delmonus, papuoštus paukščiu poromis ar pavieniais stilizuotų paukščiu motyvais, kurie, kartu su augaliniais ornamentais komponuoti delmono centre, sudaro pagrindinį dekoro akcentą arba yra tik smulkūs pagalbiniai elementai. İvairūs stilizuotu paukščiu siužetai dažni aukštuomenès aksesuarų (rankinių) puošyboje (žr. 10 lentelę). Viename rankdarbyje siuvinèta po vieną, du ir keletą (3-4) paukščiu. Dažna simetriška kompozicija, kai vienas į kitą atsisukusius arba vienas nuo kito nusisukusius paukštelius jungia centrinis stilizuoto augalo motyvas. Didelè dalis siuvinètų paukščiu laisvai komponuoti vešlios augmenijos fone arba šalia kitu stilizuotų siužetinių ornamentų. Siuvinèta perteikiant natūralistinį konkretaus paukščio spalvini koloritą (atpžịstamas prototipas) arba sukurti nauji (rojaus paukščių) spalviniai deriniai.

10 lentelè

\section{Ornamento motyvai. Paukščiai}

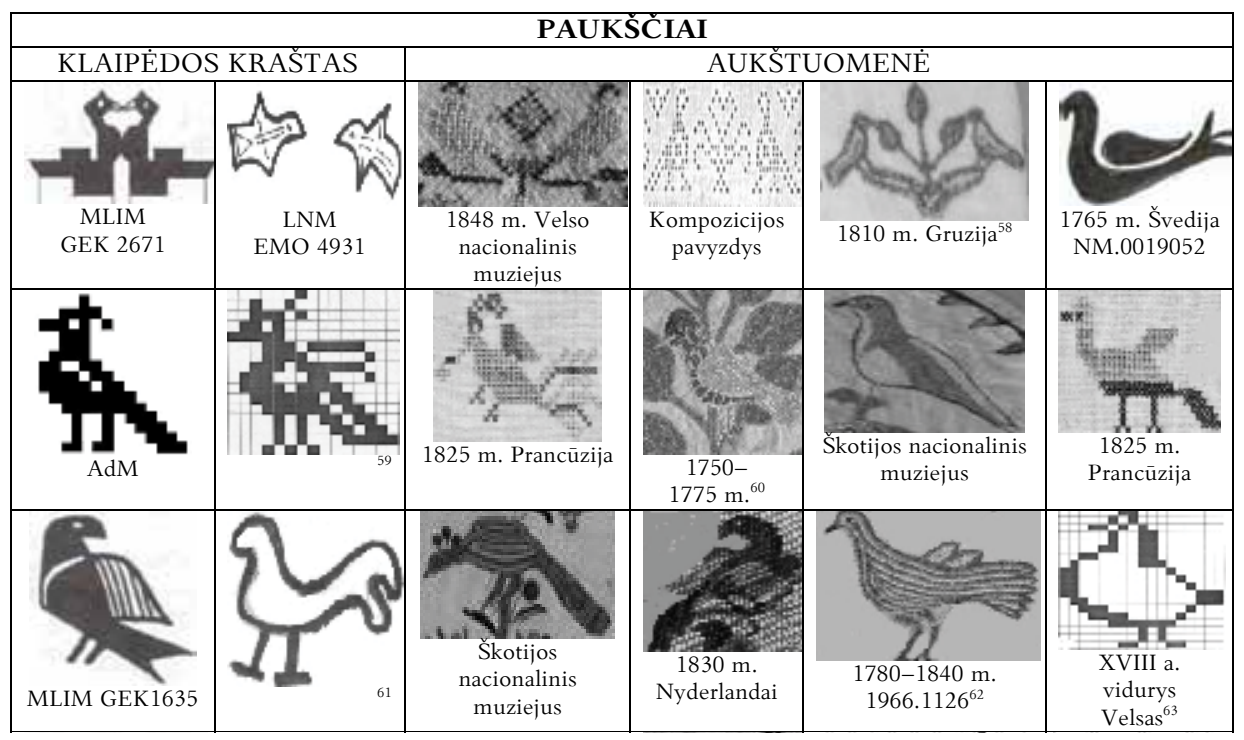

58 Very Rare Great 1800s 19 ${ }^{\text {th }}$ c. Georgian Regency Needlework Pocket from 1810.

59 The Burrell Collection 1700. The front of the pocket is made from one piece of linen and lined with linen. It is embroidered overall in flowers, stems, fruit and birds in green, yellow and red wool in cross stitch and below the opening are the initials and date 'EH 1700'.

60 Jungtinès Amerikos Valstijos. 1954.0055.001.

61 Publikuota: Tamošaitis 1979 - Antanas and Anastasia Tamošaitis. Lithuanian national costume. Lithuanian folk art institute. Toronto, Canada, 200.

62 http://museumcollection.winterthur.org.

63 Sankt Fagans Nacionalinis istorijos muziejus. 


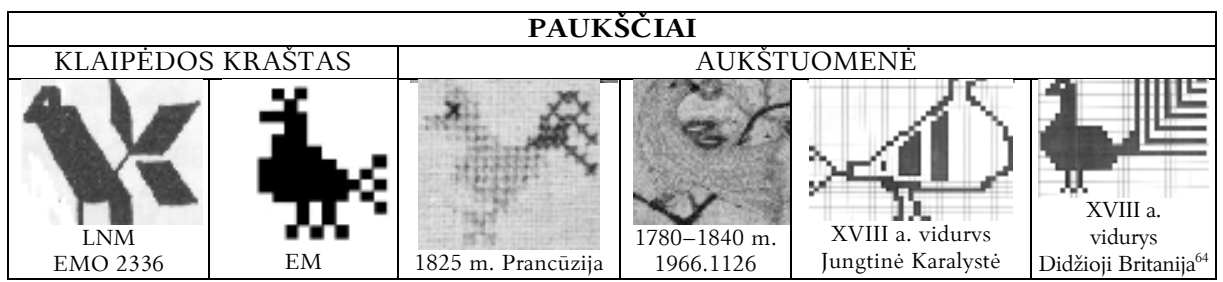

Yra išlikęs vienas delmonas, pagamintas XIX a. pabaigoje - XX a. pradžioje, su išsiuvinètomis žmonių figūrèlèmis ir gèlių žiedais. Mažosios Lietuvos istorijos muziejus (Klaipėdoje) ji iૃsigijo (1959 m.) iš Šatrių kaimo (Klaipèdos rajonas, Dauparų-Kvietinių seniūnija) gyventojos Onos Beržinskienès. Ši delmona savininkè nešiojo savo jaunysteje. Delmonas (MLIM GEK 2705) pasiūtas iš juodos storos namų audimo (kanapinès) medžiagos, siuvinètas storais medvilniniais (raudonos, mèlynos, rožinès, žalios, rudos, geltonos spalvų) siūlais, prie jo prisiūta šimtaraštė juostelè. Ornamento kompozicija ir kišenès technologinė charakteristika leidžia teigti, kad šiam delmonui dekoruoti panaudotas siauras siuvinètas audinys, o kompozicijos asimetrija natūraliai susidèliojo atskiras siuvinètas dalis susiuvus ì vieną plokštumą. Žmonių figūrèlių siuvinèjimas dekoruojant kišenes nebūdingas nagrinejjamų kaimyninių tautų rankdarbiams, tačiau dažnas aukštuomenès siuviniuose (žr. 11 lentelę). Stilizuotos žmonių figūrèlès aptinkamos ir Klaipėdos krašto (Klaipėdos bei Šilutės rajonų) šimtaraščių juostų ornamentikoje. Siaurose (1,6-2 cm pločio) rinktinėse juostelèse išausta daugybė (iki 30 vnt. 2 metrų ilgio juostelès atkarpoje) skirtingų ornamentų, tarp kurių aptinkame ir stilizuotas žmonių (dažniausiai moterų) figūrèles (žr. 12 lentelę).

Ornamentų siužetų šaltiniai. Lietuvos miestuose nuo XV a. įvairių brolijų ir cechų sukurti puošnūs rankdarbiai ir turtingųjų buityje naudoti atvežtiniai siuviniai savo formomis ir ornamentika dare įtaką ir pavieniams liaudies meistrams (miestelènams, samdiniams, savo derlių mieste parduodantiems ūkininkams). Profesionaliojo ir liaudies meno sąveika pastebima nuo XVIII a. antrosios pusès (Gaigalienė 1988). Kartu su atvežtiniais europietiškais siužetais buvo siuvinejami ir nacionaliniai ornamentai, aptinkami tekstilès bei kitų liaudies meno šaku (keramikos, medžio dirbinių, margučių, dekoratyvinès (baldų) tapybos) ornamentikoje. XIX a. siuvinèjimas suvienodejo visuose visuomenès sluoksniuose. Kartojami seni ir atsiranda nauji siuvinejjimo būdai.

Popieriaus lapai su ornamentų pavyzdžiais, skirtais staltiesėms, užuolaidèlèms bei kitai buitinei tekstilei dekoruoti, buvo parduodami turguose (Rygoje ir kt.)

64 Carmarthenshire County Museum. Didžioji Britanija. XVIII a. vidurys. 


\section{Ornamento motyvai. Žmonių figūrèlès}

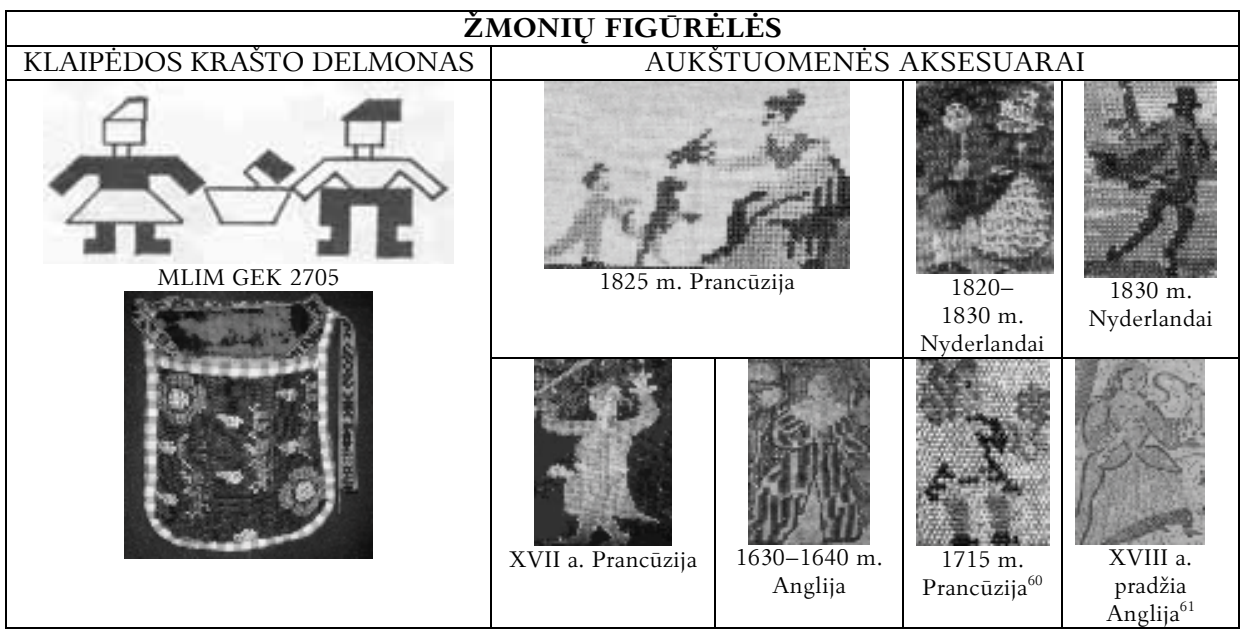

12 lentelè

Ornamento motyvai. Žmonių figūrèlès šimtaraščių juostų ornamentikoje

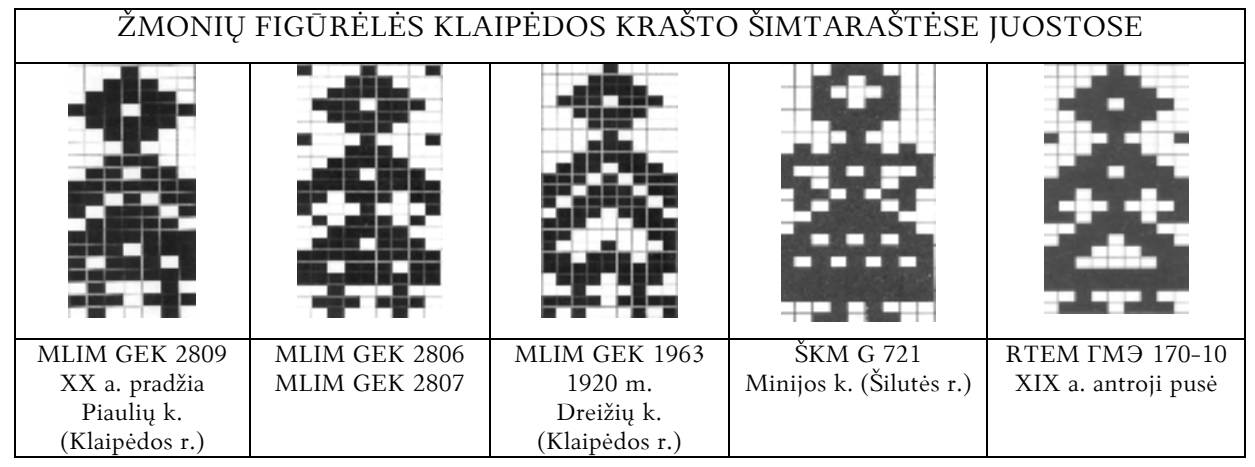

arba kaip papildomi priedai kartu su moterims skirta periodine spauda (Vokietijoje). Ornamentų elementus moterys kūrybiškai pritaikydavo ir kitų buičiai bei aprangai skirtų rankdarbių puošybai (Matulionienė 2006, 174-176). Ornamentų elementai bei ištisi siužetai išplito tarp rankdarbių mėgèjų miestuose ir kaimuose. Sẻkmingos ir skoningos pirminių pavyzdžių variacijos buvo siuvinėjamos (ir net audžiamos) darbščiųių kaimo moterų Klaipėdos krašte ir kaimyninėse šalyse.

65 Apie 1715 m. Prancūzija. Dailès muziejus, Bostonas. http://www.metmuseum.org/collection/ the-collection-online/search/230688

${ }^{66}$ XVIII a. pradžia. Anglija. Dailès muziejus, Bostonas (MFA), 53.521. 
Kad siuvinėjimo raštų pavyzdžiai keliavo iš vienos tautos į kitą, patvirtina autorès pastebėti lietuvių bei latvių buitinès tekstilès rankdarbių pavyzdžių identiški siužetai, kuriuose skiriasi tik tekstai (siuvinèti valstybine kalba). Daroma prielaida, kad iš atminties atkurtų, ne tik tiesiogiai nuo turimų pavyzdžių nukopijuotų, per dvarus ị kaimiečiu aplinką atejjusių ornamentų elementų bei jų kompoziciju šaknys kyla iš miesto aukštuomenès madų. Palyginus augalinius ornamentus, surastus liaudies rankdarbiuose, su išlikusiais aukštuomenès kišeniu pavyzdžiais, pastebimas akivaizdus ornamentų elementų panašumas (žr. 3-7 lenteles). Autorès surinkti duomenys leidžia daryti prielaidą, kad nemaža dalis ornamentu motyvų, aptinkamų liaudiškų kišenių dekore, buvo populiarūs aukštuomenès moteru siuvinètuose rankdarbiuose. Labiausiai paplitusių siužetinių ornamentų koreliacijos tyrimas patvirtina dalinę aukštuomenès madų ir tarptautinių ryšiu ittaką liaudies kostiumo dekoro formavimuisi ir kaitai.

\section{Ornamentų kūrimas ir komponavimas}

Pavienius ornamentų motyvus įvairiai komponuojant sukuriami tęstiniai (juostiniai) ir baigtiniai raštai. Geometriniai, stilizuoti augaliniai bei siužetiniai motyvai, siuvinèti kaip pagrindiniai ar savarankiški papildomi raštai arba kaip sudètiniai ornamento elementai, jungiami į bendrą kompoziciją. Kaip jau minèta, raštai sudaromi įvairiai komponuojant vienos rūšies (geometrinius ar augalinius) bei derinant skirtingų rūšių (geometrinius, augalinius ir gyvūninius) ornamentų elementus. Taip sukuriamos įvairios kompozicijų grupès, kuriomis dekoruojami ne tik rankdarbiai, bet ir kiti liaudies meno dirbiniai. Tautinio kostiumo kišenių ornamentika įvairi. Estiškos bei suomiškos kišenès dekoruotos vienos rūšies geometriniu arba augaliniu ornamentu. Švediški rankdarbiai siuvinèti derinant geometrinius ir stilizuotus augalinius ornamentus. Tokios kompozicijos, išsiuvinètos viename rankdarbyje, vadintinos mišriomis. Norvegiškų bei lietuviškų kišenių kolekcijose gausu visu trijų tipų ornamentų kompozicijų: geometrinių, augalinių bei mišrių. Augaliniu ornamentu dekoruota didžioji dalis klaipèdietiškų (54 \%) ir norvegiškų (58 \%) kišenių. Paukščių, vabzdžių, gyvūnų ir žmoniu figūrèlès aptinkamos klaipedietiškų delmonu (13 vnt.) ir norvegiškų kišenių (2 vnt.) puošyboje. Ornamento papildymas data, inicialais ar prasminiu tekstu aptinkamas klaipedietiškuose (36 \%) ir švediškuose (23\%) rankdarbiuose (Matulionienè 2006, 177-179). Dažniausiai tai smulkūs bendrosios kompozicijos elementai. Kartais tekstas ar stambus šriftas atlieka pagrindinio ornamento funkciją (žr. 13 lentelę). Lietuvininkių delmonuose siuvinètas vokiškas tekstas atspindi Klaipėdos krašto valstybinès kalbos statuso kitimą ${ }^{67}$.

${ }_{67}$ Klaipèdos krašto valstybinès kalbos statusas kito: nuo XIII a. iki 1919 m. valstybinė kalba buvo vokiečių, nuo 1923 m. iki 1939 m. kovo 23 d. - lietuvių, paskui vèl vokiečiu iki 1945 m. 


\section{Šrifto komponavimas}

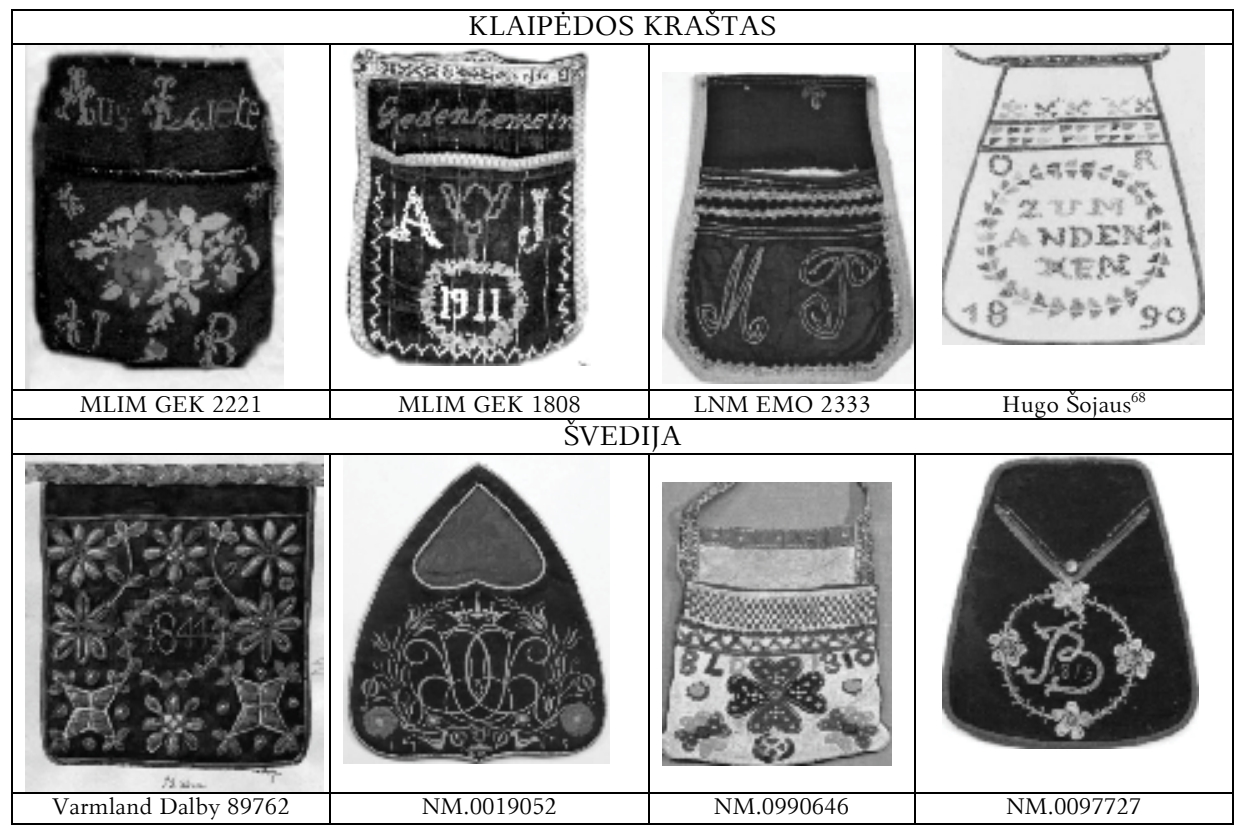

Dekoruoti rankdarbiai klasifikuotini pagal ornamentu padengto ploto bei fono santyki (žr. 14 lentelę). Šiuo požiūriu išskirtinos grupès:

1. Minimalus ornamento kiekis. Dominuoja kišenès fonas (siuvinėjamasis audinys).

2. Ornamentas ir fonas pasiskirstę tolygiai.

3. Maksimalus ornamento kiekis. Ornamentu padengtas visas siuvinejamas plotas (didžioji kišenès audinio dalis).

Mažiausiai dekoro naudota suomiškų kišenių (vadinamų irtotasku) puošyboje. Iš tiriamų 64 pavyzdžių siuvinètos tik 24 kišenès, kuriose ornamento ir fono pasiskirstymas tolygus arba išsiuvinèti tik atskiri ornamento motyvai. Minimalistiniu ornamentu pasižymi estiškos (vadinamos lahttasku) kišenès (20\%) ir lietuvininkių delmonu (20 \%) dekoras. Po keletą pavyzdžių aptinkama norvegiškų (vadinamų kjolvaska) ir švediškų (vadinamų kjolsäck ir liduvaska) kišenių puošyboje. Tolygus ornamento ir fono santykis būdingas lietuvininkių delmonams (50 \%), dažnas estų, norvegų, suomių (iki 30 \%) rankdarbiuose. Ornamento

68 Tirolio liaudies meno muziejuje (Tiroler Volkskunstmuseum) Insbruke (Austrija), aplanke 25/ Ostpreussen (Rytprūsiai) saugomi dailininkès E. V. Korff 1941 m. perpiešti bei aprašyti Hugo Šojaus muziejuje saugoti eksponatai. 
Liaudiškų kišenių ornamento ir fono santykis

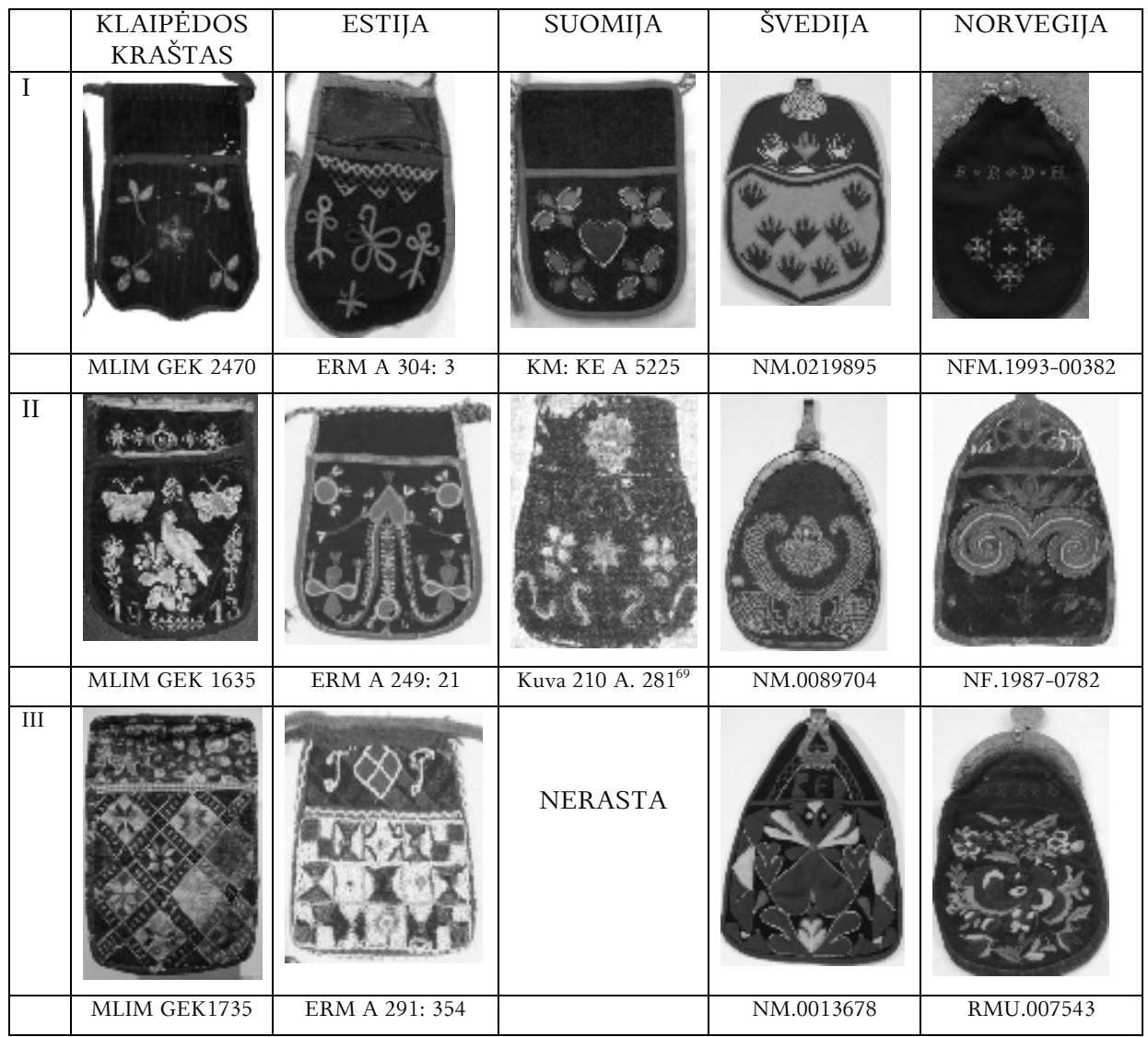

gausa, kai padengiamas visas siuvinejjamas paviršius, išsiskiria švediškos kišenès (82 \%). Didžiąią dali šių švediškų kišenių sudaro aplikavimo (ant pagrindinio audinio užsiuvamos kitų audinių skiautès) ir siuvinejjimo technikomis sukurti ornamentai, o kitų tautų rankdarbiuose ornamentai dažniausiai tik siuvinėjami. Nedidelès apimties aplikacijos (kai audinyje iškirpus lopinèlị ịdaigstoma kito audinio skiautè) kartais papildo suomiškų kišenių dekorą. Maksimaliai dekoruotos kišenès sudaro didžiąją dalį (iki 50 \%) estiškų, norvegiškų bei klaipėdietiškų rankdarbių. Estės savo kišenes padengia smulkių stiklo karoliukų ornamentu, norvegès bei lietuvininkès siuvinèja vilnoniais ir medvilniniais siūlais. Lietuvininkès mėgsta viename rankdarbyje komponuoti siūlais ir karoliukais siuvinètus ornamento elementus.

69 U. T. Sirelijus, 161. 
Dekoro elementų komponavimo būdai. Aptariant siužetinius kompozicinius elementus jau buvo minèti ir tų elementų komponavimo būdai. Apibendrinant reikia pažymèti, kad dažniausiai pasitaikantys yra trys: centrinis, juostinis ir kampinis (žr. 17 lentelę).

Centrinis (simetriškas arba asimetriškas) - puošiamas kišenès centras: siuvinejjama geometrinè figūra (rombas), stilizuotas augalinis (gèlių puokštè, vainikas) ar siužetinis (širdelè, medis) ornamentas. Visame kišenès plote įkomponuotą augala randame klaipėdietiškose, švediškose, suomiškose, norvegiškose bei aukštuomenès kišenėse. Asimetriškos augalų kompozicijos dažnos klaipėdietiškose ir norvegiškose kišenėse. Lietuvininkèms nebūdingomis geometrinių detalių kompozicijomis išsiskiria švediškos ir suomiškos kišenès.

Juostinis - komponuojamas visu kišenès perimetru; smulkių detalių apvadais įrèminamas centrinis elementas; visas kišenès plotas padalijamas ị skersines arba išilgines juostas. Būdingas lietuvininkių delmonams, pasitaiko švediškų bei estiškų kišenių kompozicijose.

Dažniausiai aptinkamas lietuvininkių juostinis ornamentas - stilizuotų augalų bei geometrinių figūrų girliandos. Jomis puošiami tekstiliniai Klaipèdos krašto rankdarbiai (žr. 15 lentelę). Identiški ornamentų elementai bei jų deriniai aptinkami lietuvininkių delmonuose, pirštinèse ${ }^{70}$, buitineje tekstilèje (staltiesių, staltiesèlių, rankšluosčių, pagalvèlių užvalkalų puošyboje).

15 lentelè

Klaipèdos krašto juostiniai ornamentai. Girliandos

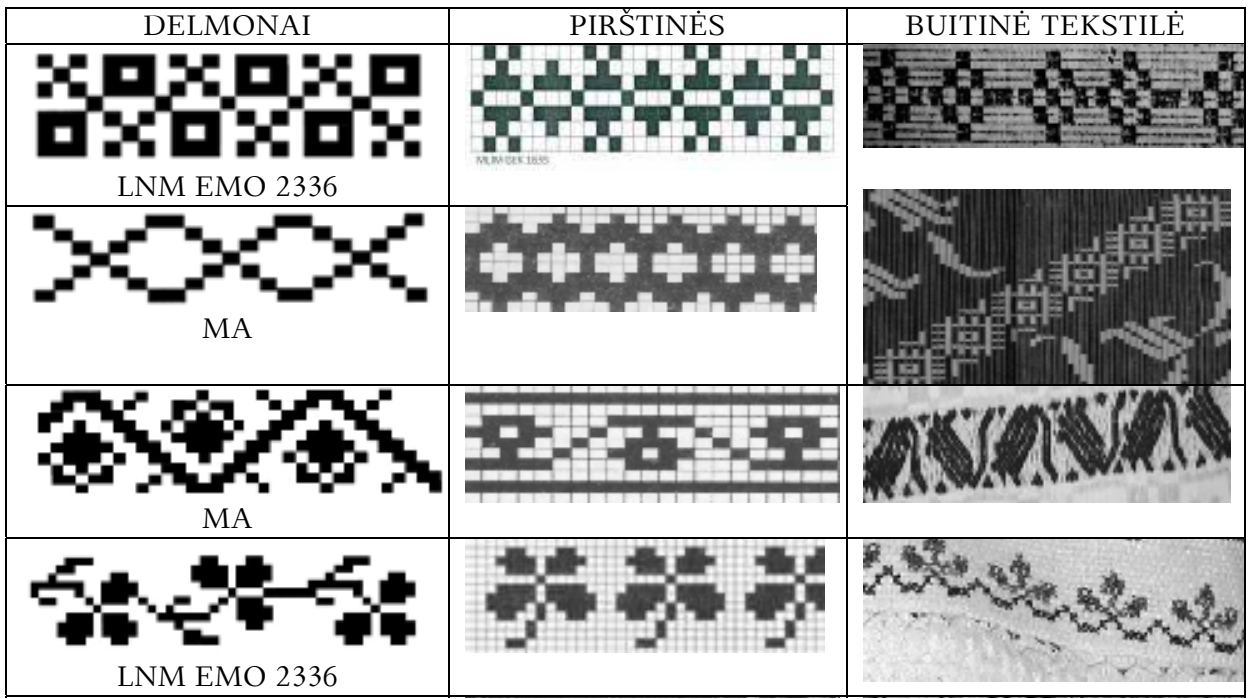

70 Merkienè, Pautieniūtė-Banionienè 1998 - Irena Regina Merkienè, Marija Pautieniūtè-Banionienè. Lietuvininkų pirštinès. Kultūrų kryžkelèje. Lietuvos etnologija 3. Vilnius, 199. 


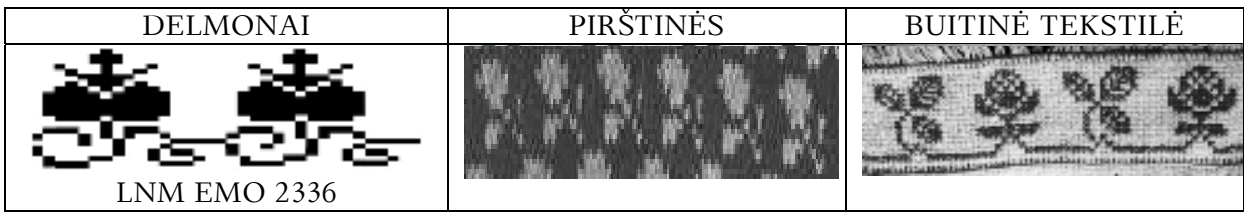

Kampinis - savarankišku ornamentu akcentuojami kišenès kampai (visi keturi arba tik du apatiniai) įrėmina siužetinę kompoziciją ar šriftą. Lietuvininkių kompozicijose puošniausi stilizuoti vijoklinių augalų motyvai, dažnai susidedantys iš konkrečių geometrinių formų. Kampuose išsiuvinėti natūralistiniai smulkūs žiedeliai ar šakelès - gerokai paprastesni (žr. 16 lentelę).

16 lentelè

Klaipèdos krašto kampiniai ornamentai

\begin{tabular}{|l|l|l|l|}
\hline & & \\
\hline
\end{tabular}

17 lentelè

Kišenių ornamento elementų komponavimo būdai: centrinis, juostinis, kampinis

\begin{tabular}{|c|c|c|c|c|c|}
\hline & $\begin{array}{l}\text { KLAIPE்DOS } \\
\text { KRAŠTAS }\end{array}$ & ESTIJA & SUOMIJA & ŠVEDIJA & NORVEGIJA \\
\hline \multirow[t]{2}{*}{ I } & & & & & \\
\hline & LNM EMO 1895 & ERM A 291: 356 & E M & NM.0002391 & E M Tartu \\
\hline \multirow[t]{2}{*}{ II } & $=$ & & 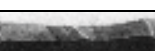 & & \\
\hline & ŠM GEK 159 & ERM 16529 & EM Jaala & NM.0091240 & Akershus \\
\hline
\end{tabular}

${ }^{71}$ http://www.norskflid.no/bunad/bunader/moere-og-romsdal/kvinnebunaden-fra-nordmoere/ loeslomme/ 


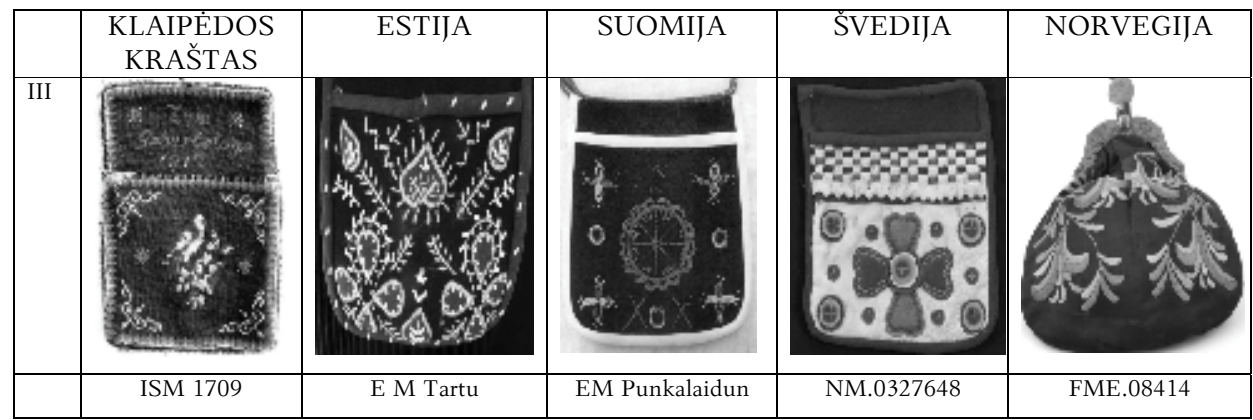

Išvados

Išnag rinejjus Klaipėdos krašto, estiškų, suomiškų, švediškų, norvegiškų liaudies kostiumo kišenių (iš viso 368 vnt.) bei įvairių tautų aukštuomenès kišenių (70 vnt.) dekoravimo aspektus, nustatyti tautinio kostiumo kišenių dekoravimo bendrumai, skirtumai bei santykis su aukštuomenès kišeniu puošyba.

\section{Baltijos regiono tautinių kostiumų kišenių dekoro bendrumai.}

Pagrindinis kišenių dekoravimo būdas - siuvinèjimas. Siuvinèjimas ant juodos spalvos audinio būdingas visoms Europos tautoms. Švedijoje populiarus siuvinèjimas ant raudono vilnonio audinio pasitaiko ir Klaipèdos krašte. Dažniausiai siuvinèta spalvingais vienos rūšies (Švedijoje, Suomijoje, Norvegijoje) vilnoniais ar šilkiniais siūlais įvairiais dygsniais (grandininiu, kilpiniu, zigzago, kryželio ir kt.). Klaipedos krašte aptinkami delmonai siuvinèti skirtingu rūšių (vilnoniais, medvilniniais, šilkiniais) ir skirtingų storių (storais bei plonais) įvairiaspalviais siūlais. Siuvinèti universalūs geometriniai bei stilizuoti siužetiniai ornamentai. Populiariausi ornamentų motyvai, aptinkami visose Baltijos regiono tautose, yra: augalas, gèlès žiedas ar puokštè, segmentinè žvaigždè, vainikas, širdelè. Visame kišenès plote ịkomponuotą augalq randame Klaipėdos krašto, švediškose, suomiškose, norvegiškose bei estiškose kišenėse. Išskirtini trys ornamentų elementų komponavimo būdai: centrinis, juostinis ir kampinis. Jiems priskirtinų pavyzdžių surasta visuose tirtuose regionuose.

\section{Baltijos regiono tautinių kostiumų kišenių dekoro skirtingumai.}

Skiautinio siuvimas ir aplikavimas aptinkamas Suomijos, Švedijos ir Estijos kišenių dekore, o Klaipèdos kraštui nebūdingas. Siuvinètas ornamentas dar būdavo papildomas stiklo karoliukais (Klaipèdos krašte) ar dekoratyvinèmis siūlèmis prisiūtais nedideliais apskritais veidrodèliais (Suomijoje). Estijoje skirtingu spalvų karoliukais buvo siuvinejamas ne tik ornamentas, bet ir visas priekinis kišenès paviršius. Suomijoje bei Estijoje ornamentuojant naudoti ir įvairūs teks- 
tilinès galanterijos dirbiniai (juostelès, kaspinai, virvutès) bei sagos. Dekoruojant kišenes įvairiai komponuojami vienodi (širdelè, žiedas ar geometrinè figūra) arba skirtingi (įvairūs siužetiniai, geometriniai bei šrifto) elementai. Vienodų elementų komponavimo variantais pasižymi švediškos kišenès (autorei pavyko rasti daugiau kaip 40 širdelès kompozicinių variantų), o skirtingų elementų gausa išsiskiria lietuvininkių delmonai.

Geometrinių bei siužetinių ornamentų elementai paplitę netolygiai. Širdelès motyvas labiausiai paplitęs švediškose kišenèse (Dalarnos regione). Jis randamas 77 \% visų dekoruotų švediškų kišenių. Lietuvininkių delmonuose širdelès motyvas naudojamas kaip papildomas savarankiškas elementas kompozicijos erdvei užpildyti arba kaip sudètinio ornamento elementas. Kitų tautu kišenių dekore širdelès motyvas gana retas. Lietuvininkių delmonuose stilizuoto augalo siužetas papildomas geometrinių elementų, paukščių bei inicialų ornamentais, dažnas vainiko motyvas.

3. Baltijos regiono tautinių kostiumų kišenių dekoro ir ornamentikos sąsajos su aukštuomenès kišenių puošyba.

Aukštuomenejje iš skiautinių siūtos kišenès buvo populiarios Škotijoje, Jungtinejje Karalystėje, tarp į Ameriką emigravusių Anglijos piliečių. Skiautiniai liaudiškose kišenèse aptinkami Suomijoje, Švedijoje ir Estijoje.

Tiek liaudies, tiek aukštuomenės kišenių dekore populiariausi ornamento elementai yra gèlès (žiedai, šakelès, puokštès, girliandos, vainikai). Aukštuomenès rankdarbių puošyboje gana dažnas gèlių puokštès krepšelyje motyvas nurodo galimą šio siužeto, aptinkamo ir lietuvininkès delmone, kilmę. Aukštuomenès kišenių siuvimui ir liaudiškų (Klaipèdos krašto) kišenių apdailai buvo naudojami ne tik siuvinèti, bet ir augaliniais ornamentais marginti audiniai.

Karūnos motyvas, aptinkamas delmony ir švediškų kišenių dekore, gana plačiai naudotas aukštuomenės rankdarbių kompozicijose. Lietuvininkių delmonu dekore rasta paukščių, vabzdžių, šunų, žmonių figūrèlių ir kitų siužetinių elementų (namas, kryžius, medis), nebūdingų kaimyninių tautų kišenių dekorui, tačiau aptinkamų aukštuomenès moterų dėvètų kišenių (ir kitų rankdarbių) puošyboje. Širdelès motyvas, labiausiai paplitęs švediškose kišenėse (Dalarnos regione), kaip kompozicijos dalis arba savarankiškas akcentas buvo siuvinėjamas ir aukštuomenès kišenèse.

Nustačius kišenių dekoravimo bei ornamentų elementų komponavimo būdus, ornamentų motyvus, jų tarpusavio koreliaciją, derinimo ypatumus ir paplitimą Baltijos regiono tautų liaudiško kostiumo kišenių dekore ir palyginus su aukštuomenès rankinių (kišenių) pavyzdžiais galima teigti, kad nemaža dalis ornamentų motyvų, aptinkamų liaudiškų kišenių dekore, buvo populiarūs ir aukštuomenės 
moterų siuvinėtuose rankdarbiuose. Atlikti tyrimai patvirtina dalinę tarptautinių ryšių bei aukštuomenès madų įtaką liaudies kostiumo dekoro formavimuisi ir kaitai.

\section{Šaltiniai ir literatūra}

Arbet 2004 - Sven Arbet. Eesti rahva rõiva ilu. Kuda rahvas, nõnda rõõvas. The beauty of Estonian folk costume. Kirjastus Varrak, Tallinn.

Astel 2006 - Eevi Astel. Taskud võõle, kotid kätte rahvariideid kandes. Tartu-Tallinn. Esti Rahva Muuseum, EstiRahvakunsti ja Käsitöö Liit.

Berg 1978 - Arnö-berg, Inga och Hazelius-Berg, Gunnel. Folkdräkter och bygdedräkter från hela Sverige. ICA-förlaget, 1978. 235 s., rikt fotoillustrerad i färg. Förlagsband. Orebro.

Bergman 2001 - Ingrid Bergman. Folk Costumes in Sweden. Published by Boktryck, Helsingborg.

Biedermann 2002 - Hans Biedermann. Naujasis simboliu žodynas. Vilnius: Mintis.

Bolsos. Sacs. The Pepin Press B. V. 2011, 77.

Duran 2011 - Laila Duran. Scandinavian Folklore. Duran Publishing AB, Sweden. Autors: Laila Duran, Folk costumes Sweden; Anne Kristin Moe, Folk costumes Norway; Britt Eklund, folk costumes Boda, Sweden.

Duran 2012 - Laila Duran. Scandinavian Folklore II. Duran Publishing AB, Sweden. Autors: Laila Duran, Swedish and Sami folk costumes; Anne Kristin Moe, Norwegian Bunads.

Fossnes 1995 - Heidi Fossnes, J. W. Cappelen Forlag. Folk costumes of Norway. T-O Grafisk A.s, Oslo.

Gaigalienè 1988 - Liuda Gaigalienè. XVI-XIX a. siuviniai LTSR istorijos ir etnografijos muziejaus fonduose. Katalogas. Vilnius.

Gimbutienè 1994 - Marija Gimbutienè. Senoviné simbolika lietuvių liaudies mene. Vilnius.

Glemžaite 1939 - Mikalina Glemžaitè. Lietuvių moterų tautiniai drabužiai. Kaunas: Moterų Šaulių Taryba, 1939.

Holst 2011 - Leena Holst. Kansallispuku. Maahenki Oy.

Ivo 2011- Sigrid Ivo. Bags: a selection from the Museum of bags and purses. Amsterdam. Tassen.

Jurkuvienè 2001 - Teresė Jurkuvienė. Lietuvių liaudies juostos. Monografija. Vilnius: Gervelè.

Kansallispukuja 1991 - Uusia Vourelman Kansallispukuja. Helmi Vuorelma Oy. Markprint.

Keskipoikela 1997 - Maria Keskipoikela. Paritaskut ja punapaita: Pohjois-Suomen kansallispuvut = National costumes in Northern Finland (Unknown Binding).

Lietuvių liaudies menas. Drabužiai. Sudarè ir parengė J. Balčikonis, S. Bernotienè, H. Kairiūkštytė, K. Galaunè, A. Mikènaitè. Vilnius, 1974.

Matulionienė 1995 - Elena Matulionienė. Delmonai - lietuvininkių puošmena. Lietuvininkų kraštas. Monografija. Kaunas: Litterae universitatis leidykla, 595-608.

Matulionienè 2005 - Elena Matulionienè. Delmonai. Klaipèdos krašto tautiniai rūbai. Atviruku rinkinys. Klaipėda: Klaipėdos universiteto leidykla.

Matulionienè 2005 - Elena Matulionienè. Klaipèdos krašto tautiniai drabužiai. Klaipėda: Klaipėdos universiteto leidykla.

Matulionienė 2006 - Elena Matulionienė. Lietuvininkių delmonai Baltijos regiono kontekste. Lietuviai ir lietuvininkai. Etniné kultūra (V). Tiltai, priedas: mokslo darbai nr. 32. Klaipèda: Klaipèdos universiteto leidykla, 165-184.

Matušakaite 2003 - Marija Matušakaitė. Apranga XVI-XVIII a. Lietuvoje. Vilnius.

Merkienè, Pautieniūtè-Banionienė 1998 - Irena Regina Merkienè, Marija Pautieniūtè-Banionienè. Lietuvininkų pirštinès. Kultūrų kryžkelèje. Lietuvos etnologija 3. Vilnius, 199.

Palaima, Balčikonis 1960 - Vytautas Palaima, Juozas Balčikonis. Lietuvių tautiniai drabužiai 7. Vilnius: Valstybinè politinès ir mokslinès literatūros leidykla. 
Sirelius 1906 - Suomen Kansallispukuja. Kuvia ja ohjeita käytäntöä varten II. Toimittanut Uuno Taavi Sirelius. Tietosanakirja Osakeyhtiön Käsiteollisuuspiirustuksia №11. Helsinki.

Somerma 1983 - Leena Holst ja Ritva Somerma: Kansallispukujen perinteinen valmistus. (Kansallispukuneuvoston vaatekappalekohtaiset ohjeet) - Kotiteollisuus 4/1983. Leena Holst ir Ritva Somerma: Tradicinė tautinių drabužių gamyba (Tautinių drabužiu tarybos rekomendacijos) Amatai 4/1983.

Šidiškienė 2005 - Irma Šidiškienė. Būti lietuve. Etninio stiliaus apranga XIX a. pabaigoje - XX a. pirmojoje pusëje. Vilnius: Versus aureus.

Tamošaitienẻ 1938 - Anastasija Tamošaitienè. Klaipėdos krašto moterų tautiniai drabužiai. Jaunoji karta, nr. 46.

Tamošaitis 1939 - Antanas Tamošaitis. Sodžiaus menas 7-8. Lietuvių moteru tautiniai drabužiai. Kaunas.

Tamošaitis 1979 - Antanas and Anastasia Tamošaitis. Lithuanian national costume. Lithuanian folk art institute. Toronto, Canada.

Tradicinés aprangos priedai 2014. Sudarytoja Ona Danutė Aleknienè. Lietuvos nacionalinis muziejus. Vilnius.

Voruta. Lietuvos istorijos dvisavaitinis laikraštis, nr. 9 (626). 2007 m. gegužès 5 d.

Zuban 1933 - Zuban, G. Deutsche Volkstrachten - Eine Sammlung deutscher Trachtenbilder (1933, 39, Scan, Fraktur).

Федорова 1997 - Галина Федорова. Карман-лакомник. Народное творчество, Но-5, 21-22.

\section{Prieiga internetu:}

http://www.kansallispuvut.fi/info.htm - Suomijos rankdarbiu muziejaus, Suomijos tautiniu drabužiu centro ir Suomijos tautiniu drabužiu tarybos kuruojamas internetinis puslapis.

http://foreverswedish.net/folk-draumlkt.html - 1905 m. Švedijos liaudies drabužiai

http://www.sverigedrakten.se/ - Švedijos tautiniai kostiumai Šiaurès šalių muziejaus archyvuose. Stokholmas, Švedija.

http://www.vads.ac.uk/collections/POCKETS - Aukštuomenès kišenių kolekcijų nuotraukų programa.

http://www.vam.ac.uk/page/t/the-collections/ - Victoria and Albert Museum. Muziejaus kolekcijos. Didžioji Britanija.

http://www.ennenjanyt.net/2006_2/referee/luutonen.pdf - Marketta Luutonen. Laukku, ihmisen paras kaveri. Straipsnis apie rankines.

http://www.estinst.ee/publications/folk_costume/ - Estijos tautinis kostiumas.

http://www.nordiskamuseet.se/en/node/2355 - muziejus Švedijoje, Stokholme.

http://www.hjorundfjord.no/?komponent=artikkel\&handling=les\&artikkel=1615 - norvegu liaudiški kostiumai iš Hjørundfjord.

http://folkcostume.blogspot.com/2014_09_01_archive.html - siuvinëjimas kryželiu Vokietijoje.

http://www.limis.lt; http://www.limis.lt/greita-paieska/rezultatai - Lietuvos integrali muziejų informacine sistema.

http://www.bildarchiv-ostpreussen.de/index.html.lt - Rytų Prūsijos vaizdų internetinis fotoarchyvas.

Žiūrèta: 201301 10; 201302 15; 201408 05; 201502 16; 201503 10; 20150402. 
Santrumpos

AdM - Arbeitsgemeinschaft der Memellandkreise e.V. (Klaipèdos krašto darbo grupè). Klaipėdos apskrities viešoji I. Simonaitytės biblioteka, AdM archyve GEK 100 - Gaunamų eksponatų knygoje registruotas nr. 100

EMO 1000 - Gaunamų eksponatų knygoje registruotas nr. 1000

LDM - Lietuvos dailès muziejus

LD - Liaudies dailè

LNM - Lietuvos nacionalinis muziejus

MLIM - Mažosios Lietuvos istorijos muziejus

ŠAM - Šiaulių „Aušros“ muziejus

ŠM - Šilutès muziejus

E. M. - Elena Matulionienè

KKM - Klaipèdos kraštotyros muziejus

GS - privati nuosavybè

EM - privati nuosavybė

PR - Prūsijos muziejus Karaliaučiuje

ERM - Eesti Rahva Muuseum - Estijos nacionalinis muziejus

NM.0129726 - Nordiska museet - Šiaurès muziejus

NFM.1993 - 00382 - Nordfjord Folkemuseum - Nordfjord liaudies buities muziejus Norvegijoje, Sandane

NF.1987-0782 - Norsk Folkemuseum - Norvegijos liaudies muziejus

RMU.007543 - Rørosmuseet - Røros muziejus Norvegijoje, Røros regione

Värmland Dalby 89762 - Švedija, Värmland Dalby parapija

\section{Elena Matulionienè}

\section{POCKET ORNAMENTATION OF THE BALTIC REGION NATIONAL COSTUME}

The current article deals with the folk costume pockets of the Klaipeda region, Estonia, Finland, Sweden and Norway (a total of 368 units) and diverse national upper-class pocket decorations (70 items). The research helped to identify techniques for decorating pockets and special features of themed patterns. It also helped to establish similarities, differences and relationships between decorations for national costumes and upper-class clothes.

The decorating techniques for national costumes and upper-class clothes are the following: quilting sewing, embroidery and applique. Quilting and applique characteristically belong to Swedish, Finnish and Estonian pockets. Applique 
technique is characterized by decoration of pockets by simple isolated ornaments into a complex symmetrical composition. Upper-class quilt sewn pockets were popular in Scotland and the UK, later they spread to America with emigrants from England. Embroidery is the main type of pocket decoration. Embroidery on black fabric is characteristic for all European nations. In Sweden embroidery is popular on red woolen cloth. Most often colorful embroidery is performed with one type of thread: silk or wool. In Klaipeda region, however, this needlework combines different types of yarn as well as different colors. In Klaipeda region glass beads are added to the embroidered ornament, and in Finland it is common to use small circular mirrors in decorative sewing. In Estonia beads of different colors are not only a part of an ornament, but they cover the entire front surface of the pocket. In Finland and Estonia, various textile haberdashery products (i.e. tapes, ribbons, cords) and buttons are also commonly used.

Pockets decoration patterns are divided into either geometrical forms (i.e. rhombuses, circles, crosses) or they contain specific plots (i.e. plants or animals). The most widespread ornaments represent: hearts, plants, stars, segmented rings and wreathes, birds and other animals, crowns. A plant found in Klaipeda region can be found on the pockets decorated in Swedish, Finnish, Norwegian and Estonian regions. Both pockets of common people and pockets of upper-class are popularly decorated with elements of a flower (i.e. blossoms, twigs, garlands, wreaths). Common people and rich people use embroidery not only on their pocket decorations, but also on the other fabric. In Lithuanian imagery it is possible to find birds, insects, dogs, human figures and other themed elements (houses, crosses, trees). These patterns are not typical on the pockets found in neighboring countries, but they sometimes occur on pockets worn by people from upper-class. Heart patterns are most commonly found on Swedish pockets (Dalarna region), they are used as a part of a bigger composition or as an independent item to emphasize the higher class.

There are three main positions for an ornamental element: center, rim or corner. These placements of an image are found in all three regions. When decorating a pocket identical images (hearts, flowers or geometrical shapes), or various images (different themes, shapes and fonts) are sometimes used. Swedish pockets have similar patterns (the author was able to find over forty types of heart compositions). Lithuanian Delmonas stands out due to the usage of abundantly different elements and patterns where geometrical shapes and themed elements are places unevenly. The image of a heart is most common among Swedish pockets (Dalarna region). It is found in $77 \%$ of all Swedish decorated pockets. In Lithuanian Delmonas style heart is used as an additional, independent element 
or as a component of a complex pattern. The image of a heart is rare among other nations. In Lithuanian Delmonas it is possible to find plants, various geometrical shapes, birds, initials, and various crowns.

The collected data indicates that a significant part of the ornamental design found in folk embroidery was also popular among embroidery produced for women from the upper-class. These findings confirm that upper-class fashion and international relations influenced formation and change of the decorations for the folk costumes. 